\title{
Adeno-Associated Virus-Based Gene Therapy for CNS Diseases
}

\author{
Michaël Hocquemiller ${ }_{,}^{1, *}$ Laura Giersch, ${ }^{1, \dagger}$ Mickael Audrain, ${ }^{2-4, \dagger}$ Samantha Parker, \\ and Nathalie Cartier ${ }^{3,4, *}$ \\ ${ }^{1}$ Lysogene, Neuilly sur Seine, France; ${ }^{2}$ Université Paris Descartes, Paris, France; ${ }^{3}$ INSERM UMR1169, Université Paris-Sud, Université Paris-Saclay, \\ Orsay, France; and ${ }^{4} C E A, D S V, I^{2} B M, M I R C e n$, Fontenay-aux-Roses, France. \\ 'L.G. and M.A. contributed equally to this work.
}

Gene therapy is at the cusp of a revolution for treating a large spectrum of CNS disorders by providing a durable therapeutic protein via a single administration. Adeno-associated virus (AAV)-mediated gene transfer is of particular interest as a therapeutic tool because of its safety profile and efficiency in transducing a wide range of cell types. The purpose of this review is to describe the most notable advancements in preclinical and clinical research on AAV-based CNS gene therapy and to discuss prospects for future development based on a new generation of vectors and delivery.

\section{INTRODUCTION}

NEUROLOGICAL DISORDERS are among the most difficult pathologies to treat because of the limited access to brain structures, which are protected by physical barriers such as the blood-brain barrier (BBB); the complexity of the CNS; and cell interactions. Gene therapy is an alternative to traditional pharmacological approaches that has made important advances over the last decade in treating the nervous system.

Experimental use of gene therapy for brain tumors has increasing promise, with a multitude of research programs using recombinant adenoassociated viral (rAAV) gene therapy with systemic or direct administration of therapeutic agents into the tumor site. This work is not considered here, as the goal to influence the proliferation of abnormal cells is not within the scope of this review. The aim of this review is to provide a thorough summary of the most notable advancements in preclinical and clinical research on $\mathrm{rAAV}$ gene delivery in treating neurodegenerative, genetic, and acquired diseases affecting the nervous system.

$\mathrm{AAV}$ is a small, nonenveloped virus that has been the subject of intense research interest from the gene therapy field. rAAVs have demonstrated remarkable evidence of efficacy and safety in a large number of animal models. They have become the most commonly used gene therapy vectors for the $\mathrm{CNS}^{1}$ because of their safety, nonpathogenic nature, and ability to infect dividing and quiescent cells in vivo, particularly neurons. rAAVs have also demonstrated longterm gene expression in vivo. ${ }^{2}$

Initial preclinical proofs of concept used firstgeneration vectors based on AAV serotype 2 . They moved from the conceptual stage to clinical trials for several inherited and acquired diseases, such as Parkinson's, Batten's, and Canavan's disease ${ }^{3}$ (Table 1). Since then, several other AAV serotypes have been isolated and engineered. AAV strains with improved tissue tropisms and biodistribution have been extensively characterized in animal models. The recombinant genome of a given serotype can be packaged into the capsid of another serotype (i.e., rAAV2/5 contains the AAV2 recombinant genome packaged in the capsid proteins encoded by the cap gene of AAV5 ${ }^{4}$ ). The AAV serotypes most studied in the CNS have been serotypes $1,2,5,8,9$, and recombinant human (rh) $10 .^{5-8}$ The effectiveness of a serotype depends on the brain region, the species, and the targeted cell type. These serotypes efficiently transduce neurons;

*Correspondence: Dr. Nathalie Cartier, INSERM UMR1169, Université Paris-Sud, Université Paris-Saclay, Orsay 94100, France. E-mail: nathalie.cartier@inserm.fr; or Dr. Michaël Hocquemiller, Lysogene, 18-20 rue Jacques Dulud, Neuilly sur Seine 92200, France. E-mail: michael.hocquemiller@lysogene.com

(c) Michaël Hocquemiller, et al., 2016; Published by Mary Ann Liebert, Inc. This Open Access article is distributed under the terms of the Creative Commons Attribution Noncommercial License (http://creativecommons.org/licenses/by-nc/4.0/) which permits any noncommercial use, distribution, and reproduction in any medium, provided the original author(s) and the source are credited. 
Table 1. Clinical Trials

\begin{tabular}{|c|c|c|c|c|c|c|c|c|c|c|c|c|c|c|c|}
\hline & Injection site & Disease & $\begin{array}{c}\text { Clinical } \\
\text { trial }\end{array}$ & Inclusion & Serotype & Transgene & Promoter ${ }^{\mathrm{a}}$ & $\begin{array}{l}\text { Dose, } \\
\min v g\end{array}$ & $\begin{array}{l}\text { Dose, } \\
\max v g\end{array}$ & $\begin{array}{l}\text { Volume, } \\
\qquad L\end{array}$ & $\begin{array}{l}\text { Speed, } \\
\mu \mathrm{L} / \mathrm{min}\end{array}$ & IS & Status & Identifier & Ref. \\
\hline \multirow{16}{*}{ 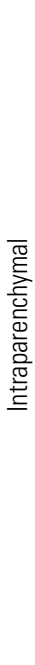 } & WM $(n=6)$ & Can & Phase I & 13 & 2 & ASP & NSE & \multicolumn{2}{|c|}{$9 \times 10^{11}$} & 900 & 2 & NA & C & NA & 15 \\
\hline & WM $(n=12)$ & LINCF & Phase I & 11 & 2 & CLN2 & CAG & \multicolumn{2}{|c|}{$1.8 \times 10^{12}-3.2 \times 10^{12}$} & 600 & 2 & NA & C & NCT00151216 & 17 \\
\hline & WM $(n=12)$ & LINCF & Phase I/II & 16 & rh10 & CLN2 & CAG & \multicolumn{2}{|c|}{$2.85 \times 10^{11}-9 \times 10^{11}$} & 1800 & 2 & NA & 0 & NCT01414985 & NA \\
\hline & WM $(n=12)$ & MPS IIIA & Phase I/II & 4 & rh10 & SGSH & PGK & \multicolumn{2}{|c|}{$7.2 \times 10^{11}$} & 720 & 0.5 & Y & C & NCT01474343 & 16 \\
\hline & $\begin{array}{l}\text { WM }(n=12) / \\
\text { Cer }(n=4)\end{array}$ & MPS IIIB & Phase I/II & 4 & 5 & NAGLU & PGK & \multicolumn{2}{|c|}{$4 \times 10^{12}$} & 960 & 0.5 & Y & 0 & ISRCTN19853672 & NA \\
\hline & WM $(n=12)$ & MLD & Phase I/II & 5 & rh10 & ARSA & CAG & \multicolumn{2}{|c|}{$1 \times 10^{12}-4 \times 10^{12}$} & NA & NA & NA & 0 & NCT01801709 & NA \\
\hline & $\operatorname{StN}(n=2)$ & Par & Phase ॥ & 16 & 2 & $\mathrm{GAD}$ & CAG & \multicolumn{2}{|c|}{$2 \times 10^{12}$} & 70 & 0.23 & NA & C & NCT00643890 & 162 \\
\hline & $\operatorname{Str}(n=4)$ & Par & Phase I & 10 & 2 & AADC & CMV & \multicolumn{2}{|c|}{$9 \times 10^{10}-3 \times 10^{11}$} & 200 & 1 & $\mathrm{~N}$ & C & NCT00229736 & 163 \\
\hline & Put $(n=8)$ & Par & Phase I\&II & 70 & 2 & NTN (CERE-120) & CAG & \multicolumn{2}{|c|}{$1.3 \times 10^{11}-5.4 \times 10^{11}$} & 80 & 2 & NA & C & $\begin{array}{l}\text { NCT00252850 } \\
\text { NCT00400634 }\end{array}$ & 106,164 \\
\hline & $\begin{array}{l}\text { Put }(n=6) / \\
\text { SN }(n=4)\end{array}$ & Par & Phase I/II & 57 & 2 & NTN (CERE-120) & CAG & \multicolumn{2}{|c|}{$9.4 \times 10^{11}-2.4 \times 10^{12}$} & 360 & $2 / 3$ & NA & 0 & NCT00985517 & 165 \\
\hline & $\operatorname{Str}(n=2)$ & Par & Phase I & 24 & 2 & GDNF & CMV & \multicolumn{2}{|c|}{$9 \times 10^{10}-3 \times 10^{12}$} & NA & NA & NA & 0 & NCT01621581 & NA \\
\hline & $\operatorname{Str}(n=2)$ & Par & Phase I & 10 & 2 & AADC & NA & \multicolumn{2}{|c|}{$7.5 \times 10^{11}-1.5 \times 10^{12}$} & NA & NA & NA & 0 & NCT01973543 & NA \\
\hline & Put $(n=4)$ & Par & Phase I/II & 6 & NA & AADC & NA & \multicolumn{2}{|c|}{$3 \times 10^{11}-9 \times 10^{11}$} & $200 / 600$ & 3 & NA & 0 & NCT02418598 & NA \\
\hline & Put $(n=2)$ & Par & Phase I & 10 & 2 & AADC & NA & \multicolumn{2}{|c|}{ NA } & NA & NA & NA & 0 & NCT01395641 & NA \\
\hline & $\operatorname{NBM}(n=4 / 6)$ & Alz & Phase I & 10 & 2 & NGF (CERE-110) & CAG & \multicolumn{2}{|c|}{$1.2 \times 10^{10}-1.2 \times 10^{11}$} & $40 / 80$ & 2 & NA & C & NCT00087789 & 79 \\
\hline & NA & Alz & Phase II & 25 & 2 & NGF (CERE-110) & CAG & \multicolumn{2}{|c|}{$2 \times 10^{11}$} & NA & NA & NA & NA & NCT00876863 & NA \\
\hline \multirow{2}{*}{ 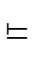 } & NA & GAN & Phase I & 20 & 9 & Gigaxonin & $\mathrm{Je}$ & \multirow{2}{*}{\multicolumn{2}{|c|}{$\begin{array}{c}\mathrm{NA} \\
1.5 \times 10^{13} \mathrm{vg} / \mathrm{kg}\end{array}$}} & NA & NA & NA & 0 & 438 & NA \\
\hline & Lom & CLN6 & Phase I/II & 6 & 9 & CLN6 & CAG & & & NA & NA & NA & 0 & NCT02725580 & NA \\
\hline \multirow[t]{2}{*}{$\geq$} & $\mathrm{PeV}$ & SMA I & Phase I/II & 15 & 9 & SMN & CAG & \multirow{2}{*}{\multicolumn{2}{|c|}{$\begin{array}{c}6.7 \times 10^{13}-3.3 \times 10^{14} \mathrm{vg} / \mathrm{kg} \\
5 \times 10^{12}-1 \times 10^{13} \mathrm{vg} / \mathrm{kg}\end{array}$}} & NA & NA & NA & 0 & 2952 & NA \\
\hline & $\mathrm{PeV}$ & MPS IIIA & Phase I/II & 9 & 9 & SGSH & U1a & & & NA & NA & Y & 0 & NCT02716246 & NA \\
\hline
\end{tabular}

${ }^{\mathrm{a}}$ The CAG promoter designation includes the CBA and CB promoter.

Alz, Alzheimer; C, completed; Can, Canavan; Cer, cerebellum; CLN6, Batten CLN6 disease; GAN, giant axonal neuropathy; IS, immunosupressor; IT, intrathecal; IV, intravenous; LINCF, Late infantile neuronal ceroid lipofuscinosis; MLD, metachromatic leukodystrophy; max vg, maximum vector genome; min vg, minimum vector genome; MPS IIIA, mucopolysaccharidosis IIIA; MPS IIIB, mucopolysaccharidosis IIIB; Lom, lombar; N, no; NA, not available; NBM, nucleus basalis of meynert; 0, ongoing; Par, Parkinson; PeV, peripheral vein; Put, Putamen; SMA I, spinal muscular atrophy type I; SN, substancia nigra; StN, subthalamique nucleus; Str, striatum; WM, white matter; Y, yes.

however, transduction of astrocytes, oligodendrocytes, or microglia is limited ${ }^{5,6,9}$ but can be improved by the use of cell-specific promoters. ${ }^{10-13}$ Transduction efficiency of these various serotypes has been further established in large-animal models such as dogs, cats, primates, and pigs (Tables 2-4), and finally used in therapeutic trials in human patients (Table 1).

Several strategies have been developed to deliver genes to the CNS. ${ }^{14}$ Initially AAV gene delivery to the brain relied on intraparenchymal injection(s) into brain regions affected by the considered disease (Fig. 1). This is a straightforward strategy for conditions involving a restricted brain region, such as, Parkinson's disease. This approach has also been evaluated in conditions affecting large regions of the brain such as lysosomal storage diseases (LSDs), with major successes in terms of preclinical proof of efficacy in numerous animal models (Table 2) and also encouraging results, with excellent safety, in human patients (Table 1) using multiple injection tracks into the brain parenchyma. ${ }^{15-17}$

Many research groups are developing cerebrospinal fluid (CSF)-based delivery, using intracerebroventricular (ICV) or cisternal or lumbar intrathecal (IT) administration (Fig. 1). These ap- proaches require high quantities of vector compared with intraparenchymal injections (Tables 1-4) but are able to deliver secreted proteins, such as growth factors, lysosomal enzymes, or apoliprotein E (APOE). However, these strategies are associated with increased leakage of the recombinant vector into the blood circulation and with consequent off-target tissue transduction and expression in peripheral organs, particularly the liver. ${ }^{18,19}$ Moreover, strategies will be required to reduce an immune response that may ultimately impair therapeutic benefit in patients. ${ }^{20}$

Several studies have focused on evaluating the ability of AAV vectors to cross the BBB in mouse models and nonhuman primates (NPHs) after IV administration. ${ }^{21-23}$ Even if encouraging results could be obtained in neonate mice, decreased transduction efficiency was observed in the primate brain, with a shift in rAAV9 tropism from neuronal to glial cells ${ }^{23}$ throughout the brain and, interestingly, into the dorsal root ganglia neurons and motor neurons within the spinal cord. ${ }^{21} \mathrm{~A}$ study comparing the ability of various rAAV strains to cross the $\mathrm{BBB}$ in mice demonstrated that rAAVrh. 10 is at least as efficient as AAV9 vectors in CNS gene transfer after systemic administration. ${ }^{24}$ 
Table 2. Preclinical trials for lysosomal storage diseases

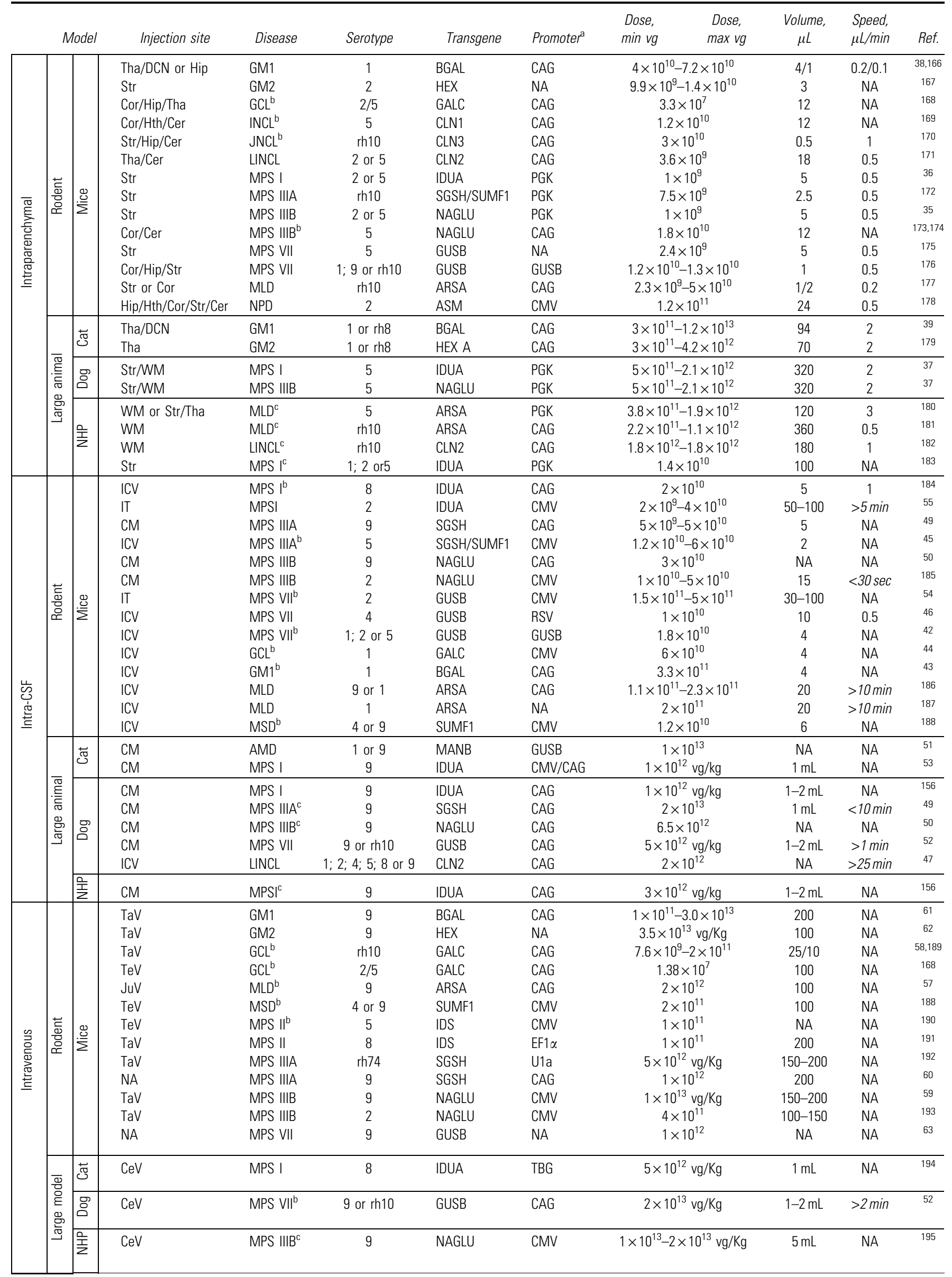


Table 2. (Continued)

\begin{tabular}{|c|c|c|c|c|c|c|c|c|c|c|c|c|}
\hline \multicolumn{3}{|c|}{ Model } & Injection site & Disease & Serotype & Transgene & Promoter $^{\mathrm{a}}$ & $\begin{array}{l}\text { Dose, } \\
\text { min vg }\end{array}$ & $\begin{array}{l}\text { Dose, } \\
\text { max vg }\end{array}$ & $\begin{array}{c}\text { Volume, } \\
\mu L\end{array}$ & $\begin{array}{l}\text { Speed, } \\
\mu \mathrm{L} / \mathrm{min}\end{array}$ & Ref. \\
\hline $\begin{array}{l}\text { 惢 } \\
\infty \\
\cong \\
\square\end{array}$ & 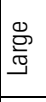 & $\pi$ & Tha/ICV & GM2 & rh8 & HEX & CAG & \multicolumn{2}{|c|}{$8 \times 10^{11}-1 \times 10^{12}$} & 340 & 2 or 15 & 196,197 \\
\hline \multirow{2}{*}{$\begin{array}{l}\frac{u}{\tilde{U}} \\
\geq\end{array}$} & 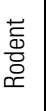 & 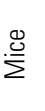 & $\begin{array}{l}\text { TeV/ICV } \\
\text { TaV/CM } \\
\text { TeV/IT }\end{array}$ & $\begin{array}{l}M^{M S D^{b}} \\
\text { MPS IIIB } \\
\text { MPS VII }\end{array}$ & $\begin{array}{c}4 \text { or } 9 \\
2 \\
2\end{array}$ & $\begin{array}{l}\text { SUMF1 } \\
\text { NAGLU } \\
\text { GUSB }\end{array}$ & $\begin{array}{l}\text { CMV } \\
\text { CMV } \\
\text { CMV }\end{array}$ & \multicolumn{2}{|c|}{$\begin{array}{c}1.2 \times 10^{10}-2 \times 10^{11} \\
5 \times 10^{10}-4 \times 10^{11} \\
3 \times 10^{10}-4 \times 10^{11}\end{array}$} & $\begin{array}{c}103 \\
5-20 \\
N A\end{array}$ & $\begin{aligned} & \mathrm{NA} \\
> & 2 \mathrm{~min} \\
& \mathrm{NA}\end{aligned}$ & $\begin{array}{l}188 \\
198 \\
199\end{array}$ \\
\hline & 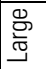 & 8 & $\mathrm{CeV} / \mathrm{CM}$ & MPS VII & 9 or rh10 & GUSB & CAG & $2.8 \times 10^{12}$ & $10^{13} \mathrm{vg} / \mathrm{Kg}$ & $1-2 \mathrm{~mL}$ & $>2 \min$ & 52 \\
\hline
\end{tabular}

${ }^{\text {a }}$ The CAG promoter designation includes the CBA and CB promoters.

${ }^{\mathrm{b}}$ Newborn animals.

${ }^{\mathrm{c}}$ The study was performed using wild type model of the animal in order to study the adeno-associated virus for the disease mentioned.

AMD, $\alpha$-mannosidosis; CeV, cephalic vein; CM, cisterna magna; Cor, cortex; DCN, deep cerebellar nuclei; GM, gagliosidosis; GCL, globoid cell leukodystrophy; Hip, hippocampus; Hth, hypothalamus; ICV, intracerebroventricular; INCL, infantile neuronal ceroid lipofuscinosis; JNCL, juvenile neuronal ceroid lipofuscinosis; LINCL, late infantile neuronal ceroid lipofuscinosis; MLD, metachromatic leukodystrophy; MPS, mucopolysaccharidosis; MSD, multiple sulfatase deficiency; NPD, Niemann-Pick disease; IP, intraparenchymal; JuV, jugular vein; Str, striatum; TaV, tail vein; TeV, temporal vein; Tha, thalamus.

\section{rAAV GENE THERAPY FOR NEURODEGENERATIVE DISEASES}

Progress in rAAV gene therapy has allowed for novel treatments of both genetic and acquired neurodegenerative diseases such as LSDs, Alzheimer's disease $(\mathrm{AD})$, Parkinson's disease (PD), Huntington's disease (HD), amyotrophic lateral sclerosis (ALS), and spinal muscular atrophy (SMA). Exciting treatment results have been obtained in animal models of the corresponding human diseases and clinical trials have been, or soon will be, launched.

\section{Lysosomal storage disorders}

LSDs are a group of more than 50 individual inherited metabolic diseases resulting from the deficiency of a lysosomal function responsible for progressive storage of undigested or partially digested materials, leading to cellular and metabolic dysfunction. ${ }^{25}$ Although individually rare, they have a collective incidence of approximately 1 per 7000 live births, ${ }^{26}$ and at least $70 \%$ of all LSDs have a significant CNS component that is typically characterized by neuroinflammation and neurodegeneration in multiple brain regions. ${ }^{27}$

Several features of LSDs make them ideal candidates for gene therapy. Each LSD is a single-gene recessive disorder with a relatively well-understood underlying molecular basis. Cross-correction opens the possibility of genetically modifying a relatively small number of cells so that they express and secrete supraphysiological levels of the deficient enzyme, which can then correct a wide range of cell types at a distance. ${ }^{28}$ A portion of newly synthesized lysosomal enzymes can be secreted and internalized by neighboring cells via mannose 6-phosphate receptors that are present on the plasma membrane. In the CNS, circulating lysosomal enzymes can diffuse via the ventricular system or be transported from the site of production to distal sites via axonal transport. ${ }^{29}$ Levels of induced gene expression are generally not critical. Low levels of residual enzyme activity resulting from missense mutations are often associated with significant impacts on the clinical course of the disease. ${ }^{30}$ Enzyme activities of less than $10 \%$ of the physiological level may therefore be sufficient to have a clinical impact on the disease course. Tight regulation of gene expression is not required because no deleterious effects are associated with supraphysiological levels of most of the lysosomal enzymes. The identification or development of small- and large-animal models recapitulating the clinical course of LSDs has been and is instrumental in evaluating therapeutic strategies. ${ }^{31}$

Several strategies of rAAV infusion have been developed and tested in animal models of neuropathic LSDs via systemic administration as well as direct injection into the CNS through the brain parenchyma or the CSF. Main preclinical studies are listed in Table 2 and results of this research are summarized below.

Intraparenchymal delivery. Intraparenchymal injection may effectively treat the CNS of patients with neuropathic LSDs because rAAV and secreted enzymes can be transported to areas distal from the injection sites. ${ }^{29,32}$ The relative low dose required, compared with systemic or CSF administration, ${ }^{33}$ in an immune-privileged site like the brain also limits the impact of a potential preexisting immunity to AAV serotypes. ${ }^{34}$ Various sites of injection into the brain (cortex, striatum, hippocampus, thalamus, ventral tegument, cerebellum), using various AAV serotypes (1, 2, 5, 9, rh8, and rh10), have been tested in mouse models of neuropathic LSDs such as $\mathrm{GM}_{1}$ and $\mathrm{GM}_{2}$ gangliosidosis, globoid cell leukodystrophy (GCL), 
Table 3. Preclinical trials for neurodegenerative diseases

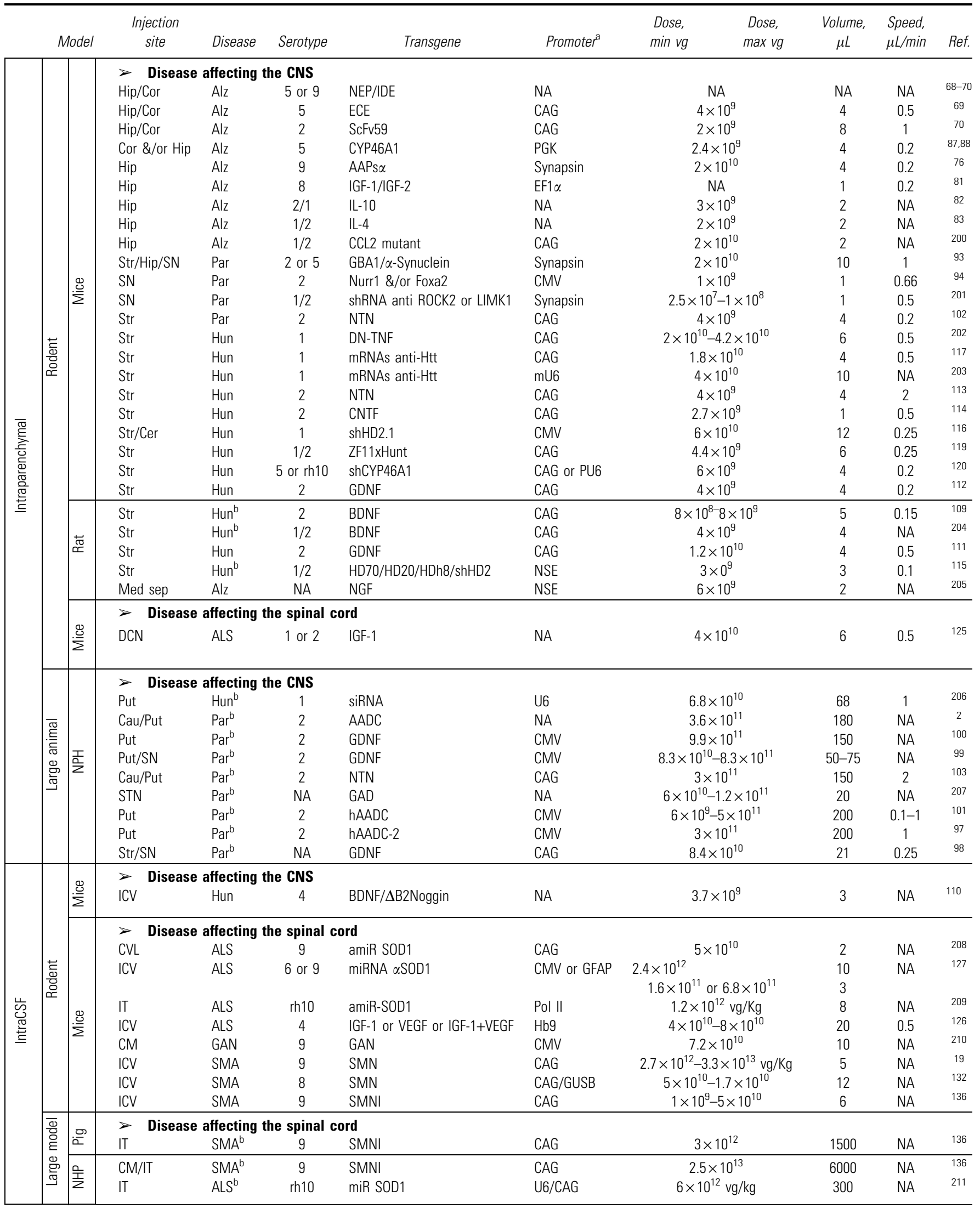


Table 3. (Continued)

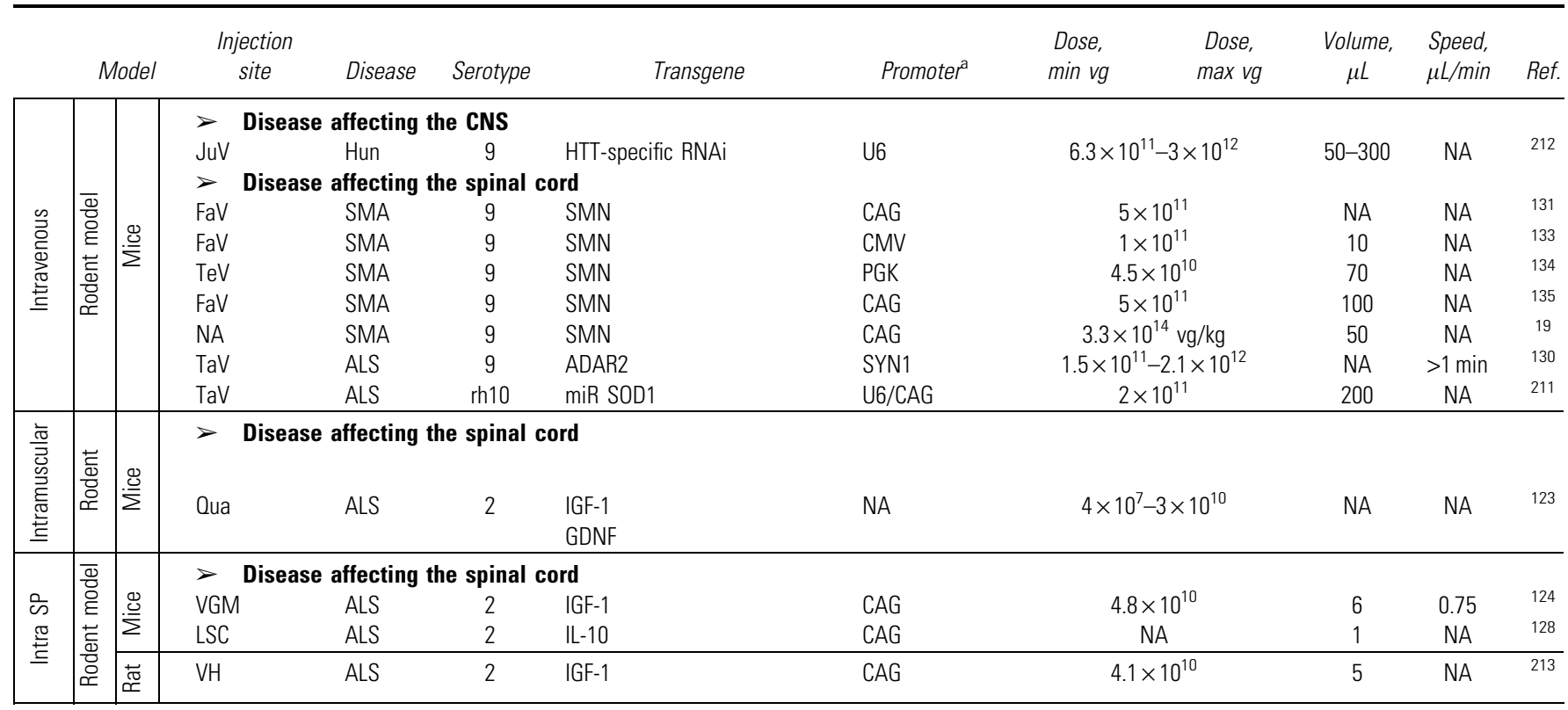

${ }^{\mathrm{a}}$ The CAG promoter designation includes the CB and CBA promoter.

${ }^{\mathrm{b}}$ The study was performed using wild type model of the animal in order to study the disease mentioned

ALS, amyotrophic lateral sclerosis; Alz, Alzheimer; Cau, caudate; FaV, facial vein; GAN, giant axonal neuropathy; Hun, Huntington; LC, lumbar cord; LSC, lumbar spinal cord; Med Sep, medial septum; Qua, quadriceps; SMA, spinal muscular atrophy; STN, sub-thalamique nucleus; Ven, ventricle; VGM, ventral gray matter; VH, ventral horn.

Niemann-Pick disease (NPD) type A, infantile and late infantile neuronal ceroid lipofuscinosis (INCL and LINCL), metachromatic leukodystrophy (MLD), and mucopolysaccharidosis (MPS) types I, III, and VII (Table 2). These studies showed that AAV vectors, injected into the parenchyma, are able to lead to widespread enzyme distribution as well as biochemical and histological correction in large regions of the mouse brain, resulting in improved behavioral symptoms, motor function, and life span. These initial data obtained in LSD mice were replicated in large-animal disease models in which multiple parenchymal injections or injection into specific CNS structures with high interconnectivity are more representative of clinical transferability. For example, widespread expres-

Table 4. Preclinical trials for epilepsy and pain

\begin{tabular}{|c|c|c|c|c|c|c|c|c|c|c|c|}
\hline \multicolumn{3}{|c|}{ Model } & Injection site & Disease & Serotype & Transgene & Promoter $^{\mathrm{a}}$ & Dose, $\min v g \quad$ Dose, $\max v g$ & Volume, $\mu \mathrm{L}$ & Speed, $\mu \mathrm{L} / \mathrm{min}$ & Ref. \\
\hline \multicolumn{12}{|c|}{ > Epilepsy } \\
\hline \multirow[b]{2}{*}{ 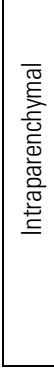 } & \multirow[b]{2}{*}{ 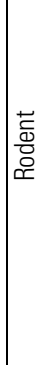 } & $\stackrel{\stackrel{\mathscr{U}}{\Sigma}}{\sum}$ & Hip & Epilepsy & 8 & ADK & gfaABC1D & $2 \times 10^{9}$ & 2 & 1 & 143 \\
\hline & & 華 & \begin{tabular}{l} 
Hip \\
Hip \\
Hip \\
Pir Cor \\
Hip \\
Inf Col \\
Inf Col or \\
\multicolumn{1}{c}{ Temp Cor }
\end{tabular} & $\begin{array}{l}\text { Epilepsy } \\
\text { Epilepsy } \\
\text { Epilepsy } \\
\text { Epilepsy } \\
\text { Epilepsy } \\
\text { Epilepsy } \\
\text { Epilepsy }\end{array}$ & $\begin{array}{c}1 \text { and } 2 \\
1 \\
2 \\
2 \\
1 / 2 \text { or } 2 \\
\text { NA } \\
\text { NA }\end{array}$ & $\begin{array}{l}\text { NPY } \\
\text { NPY } \\
\text { GDNF } \\
\text { NPY } \\
\text { NPY } \\
\text { FIB-GAL or GAL } \\
\text { NRIA or PINA }\end{array}$ & $\begin{array}{l}\text { NSE } \\
\text { CAG } \\
\text { CAG } \\
\text { CAG } \\
\text { NSE } \\
\text { CMV } \\
\text { CMV }\end{array}$ & $\begin{array}{c}6 \times 10^{10} \\
6.2 \times 10^{10} \\
4.1 \times 10^{9}-6.3 \times 10^{9} \\
1.2 \times 10^{10}-1.3 \times 10^{10} \\
6.4 \times 10^{9}-1.3 \times 10^{10} \\
1.75 \times 10^{7}-1 \times 10^{9} \\
1 \times 10^{9}\end{array}$ & $\begin{array}{c}6 \\
12 \\
3 \text { or } 6 \\
4 \\
6 \text { or } 12 \\
1 \\
1\end{array}$ & $\begin{array}{c}0.2 \\
1 \\
0.2 \\
\mathrm{NA} \\
\mathrm{NA} \\
>9 \mathrm{~min} \\
>9 \mathrm{~min}\end{array}$ & $\begin{array}{c}214 \\
215 \\
142 \\
139 \\
138 \\
141 \\
216\end{array}$ \\
\hline \multicolumn{12}{|c|}{$>$ Neuropathic pain (NP) } \\
\hline \multirow{2}{*}{$\begin{array}{l}\text { 峛 } \\
\text { ț } \\
\text { 竧 }\end{array}$} & \multirow{2}{*}{ 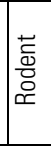 } & 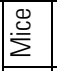 & IT & Chronic NP & 9 & shRNA anti TRPV1 & hU6 & $2 \times 10^{13}$ & 10 & $>2 \min$ & $\overline{148}$ \\
\hline & & 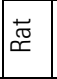 & $\begin{array}{l}\text { IT } \\
\text { IT }\end{array}$ & $\begin{array}{l}\text { Diabetic NP } \\
\text { Chronic NP }\end{array}$ & $\begin{array}{l}5 \\
8\end{array}$ & $\begin{array}{l}\text { shRNA anti } \mathrm{Na}_{\mathrm{v}} 1 \times 3 \\
\mathrm{pp} \beta \mathrm{EP} \text { and/or IL-10 }\end{array}$ & $\begin{array}{l}\text { NA } \\
\text { CMV }\end{array}$ & $\begin{array}{c}3.5 \times 10^{11} \\
3 \times 10^{10}\end{array}$ & $\begin{array}{c}5 \\
15 \\
\end{array}$ & $\begin{aligned} & N A \\
> & 1 \text { min }\end{aligned}$ & $\begin{array}{l}147 \\
217\end{array}$ \\
\hline $\begin{array}{l}\text { के } \\
\stackrel{\widetilde{E}}{=}\end{array}$ & $\mid$ & 華 & $\begin{array}{l}\text { DRG } \\
\text { DRG } \\
\text { SGM }\end{array}$ & $\begin{array}{l}\text { Chronic NP } \\
\text { Chronic NP } \\
\text { Chronic NP }\end{array}$ & $\begin{array}{c}6 \\
2 \\
N A\end{array}$ & $\begin{array}{l}\text { CBD3 } \\
\text { shRNA anti } \mathrm{Na}_{\mathrm{v}} 1.3 \\
\text { BDNF }\end{array}$ & $\begin{array}{l}\text { CMV } \\
\text { hU6 } \\
\text { CMV }\end{array}$ & $\begin{array}{c}5 \times 10^{9} \\
2.7 \times 10^{10}-1.4 \times 10^{11} \\
5 \times 10^{5} \mathrm{IU}\end{array}$ & $\begin{array}{l}2 \\
2 \\
1\end{array}$ & $\begin{aligned} & >5 \min \\
& 0.4 \\
> & 2 \min \end{aligned}$ & $\begin{array}{l}145 \\
146 \\
144\end{array}$ \\
\hline
\end{tabular}

${ }^{a}$ The CAG promoter designation includes the CBA promoter.

DRG, dorsal root ganglion; Inf Col, inferior colliculus; NP, neuropathic pain; Pir Cor, piriform cortex; SGM, spinal gray matter; Temp Cor, temporal cortex. 


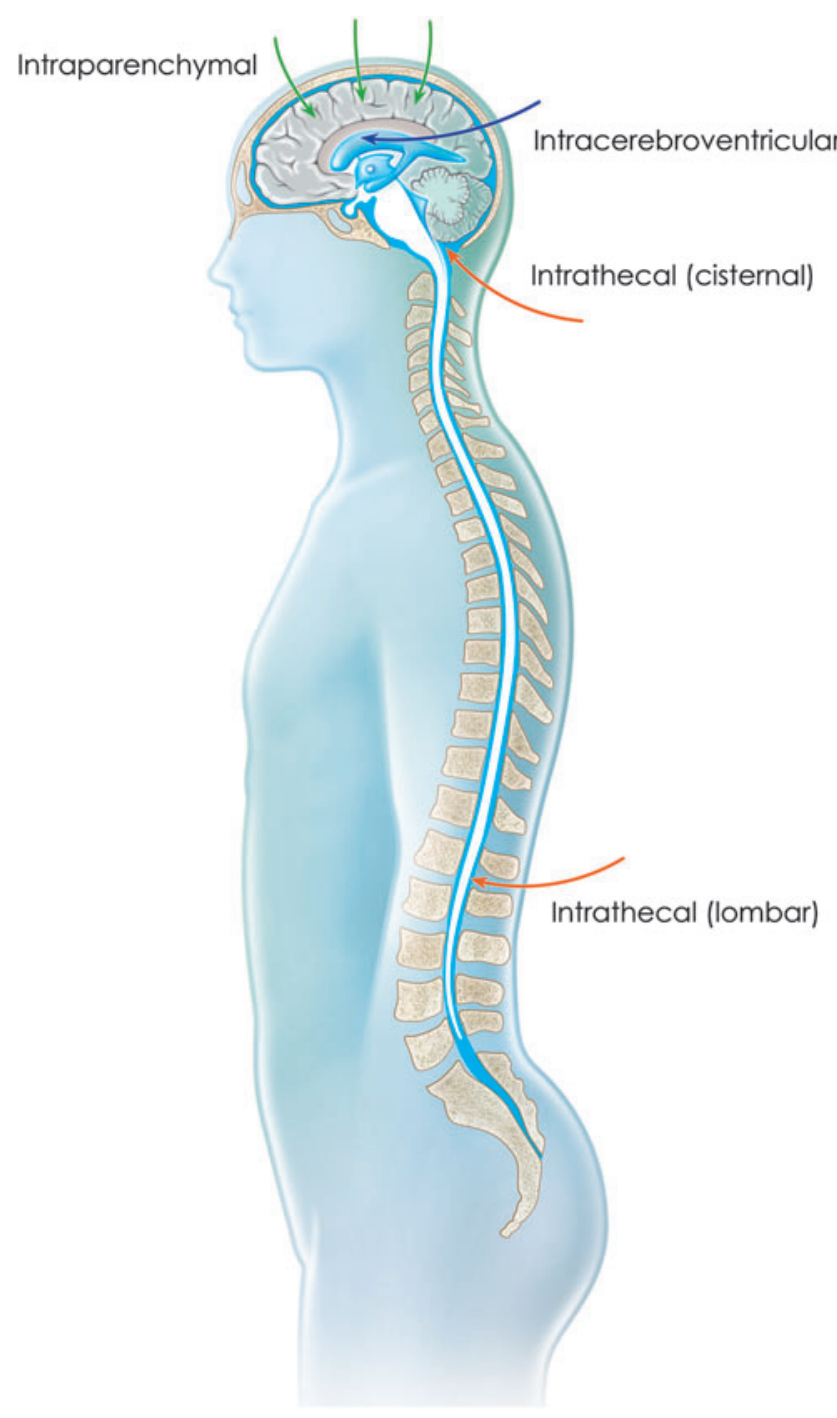

Figure 1. Routes of administration targeting the CNS by direct injection into the parenchyma or by injection into the cerebrospinal fluid via the intracerebroventricular or intrathecal (cisternal or lumbar) route.

sion of enzyme throughout the brains of MPS I and MPS IIIB mice after injection of rAAV5 into the striatum was also observed in MPS I and MPS IIIB dogs treated by a similar approach. ${ }^{35-37}$ Injection of rAAV1 encoding $\beta$-galactosidase into the thalamus and deep cerebellar nuclei of $\mathrm{GM}_{1}$ gangliosidosis mice was also successful in the feline model, with rAAVrh8 leading to long-term clinical improvement and survival. ${ }^{38,39}$ Intraparenchymal injections are particularly applicable to LSDs with severe neurological but moderate systemic involvement, and phase I/II clinical trials have been performed in LINCL, MPS IIIA, MPS IIIB, and MLD (Table 1).

The first phase I/II trial of AAV intraparenchymal injections was for Canavan disease, ${ }^{40}$ a pediatric neurodegenerative disorder associated with mutations in the gene encoding aspartoacylase (ASPA), an enzyme that converts $N$-acetyl-aspartate (NAA) into acetate and aspartate. Results have proved the feasibility and overall safety of rAAV injection into the brain via multiple sites of vector administration. Humoral immune response against the vector was observed in 3 of the 10 subjects. ${ }^{41}$ Long-term follow-up indicated a decrease in substrate levels in the brain of some patients and the stabilization of clinical disease. ${ }^{15}$ A phase I clinical trial in 10 patients with LINCL was performed by direct injection into the brain parenchyma of rAAV2 carrying the human CLN2 gene. No safety issue related to the product or the manner of administration was reported, and there was evidence of slowing disease progression. ${ }^{17} \mathrm{~A}$ phase I/II clinical trial in LINCL is currently ongoing with a second-generation AAVrh.10-based vector that confers greater enzyme distribution within the brain and a better immunogenicity profile than rAAV2. rAAVrh. 10 was also tested for intracranial delivery of $N$ sulfoglucosamine sulfohydrolase $(S G S H)$ and the sulfatase-modifying enzyme factor 1 (SUMF1) genes in patients with MPS IIIA. The administration of the vector was safe and well tolerated by the four patients included in the trial after 1 year. Stabilization in three patients and a possible improvement in one patient were observed. ${ }^{16}$ In addition, a phase I/II clinical trial for MPS IIIB, using AAV5 to express $N$-acetyl- $\alpha$-glucosaminidase (NAGLU), is ongoing as well as a phase I study using AAVrh.10 for MLD (Table 1). Although further follow-up is necessary, these initial results suggest that intraparenchymal AAV-based gene therapy is a realistic option for neuropathic LSDs.

CSF delivery. Direct delivery to the CSF is an alternative route that has been tested with various AAV serotypes $(1,2,4,5,8,9$, rh8, and rh10) via ventricles, cisterna magna, or spinal cord into small- and large-animal models of various LSDs such as $\mathrm{GM}_{1}$ and $\mathrm{GM}_{2}$ gangliosidosis, GCL, LINCL, MLD, multiple sulfatase deficiency (MSD), $\alpha-$ mannosidosis (AMD), and MPS I, IIIA, IIIB, and VII (Table 2). Initial proof of concept was made in newborn MPS VII mice where ICV injection of rAAV1, 2, and 5 resulted in the expression of $\beta$ glucuronidase (GUSB) in broad regions of the CNS. ${ }^{42}$ Similar observations were reported with rAAV1 in newborn mouse models of GCL and $\mathrm{GM}_{1}$ gangliosidosis ${ }^{43,44}$ and with rAAV5 in MPS IIIA newborn pups. ${ }^{45}$ Even though broad CNS distribution in newborn mice could be increased by the potential immaturity of the ependymal barrier, or by its disruption favored by the large volume of injection, direct targeting of ependymal cell lining 
by rAAV4 in the adult mouse model of MPS VII, ${ }^{46}$ or by rAAV2 in the LINCL dog model, also led to broad distribution of enzyme in the CNS associated with therapeutic benefits. ${ }^{47}$ However, because of the rapid turnover rate of the ependymal cells, ${ }^{48}$ long-term benefits of this approach need to be confirmed. rAAV9 or rAAVrh10 injected into the cisterna magna showed favorable phenotypic outcomes in animal models of MPS types IIIA and $\mathrm{B},{ }^{49,50}$ as well as in large-animal models of AMD, ${ }^{51}$ MPS VII, ${ }^{52}$ and MPS I. ${ }^{53}$ Potential additional positive effects of this approach on the non-CNS pathology have been observed but only in the absence of serum antibodies against the vector. ${ }^{49}$ Intracisternal administration, although easily accessible in animal models, is more problematic to translate into humans. A less invasive route into the CSF via lumbar intrathecal injection showed positive results of enzyme distribution in the brain of MPS I and MPS VII mouse models, using rAAV2 ${ }^{54,55}$ but have not yet been described in the brain of larger animal models. A first clinical trial in Batten CLN6 has been launched with a self-complementary AAV9 carrying the CLN6 gene administered intrathecally by lumbar puncture (NCT02725580). The minimum calculated dose in this clinical trial (i.e., $1.2 \times 10^{14}$ genome copies [GC] for a 1-year-old child of $\sim 8 \mathrm{~kg}$ ) is already 30 -fold higher than the highest dose $\left(4 \times 10^{12} \mathrm{GC}\right)$ tested so far in intraparenchymal injection clinical trials (Table 1).

Intravenous delivery. The capacity of the AAV9 or AAVrh10 serotype to cross the $\mathrm{BBB}^{23,56}$ has led to the exploration of intravenous (IV) injections as an alternative to treat neuropathic LSD (Table 2). Proof of concept has been shown in neonatal GCL or MLD mice. ${ }^{57,58}$ AAV9 IV administration has shown an impact on the CNS pathology of older animal models in MPS III types A and $B^{59,60}$ and $\mathrm{GM}_{1}$ gangliosidosis. ${ }^{61}$ However, the efficiency of CNS transduction seems to be more limited in older mice as evaluated in $\mathrm{GM}_{2}$ gangliosidosis. ${ }^{62}$ Moreover, transduction patterns observed in mice can be different from larger animal species. ${ }^{23}$ The nature of the storage can also limit the efficacy of this approach, as observed in the MPS VII model where accumulation of sialic acid within the CNS, an inhibitor of AAV9 transduction, precluded any CNS benefit. ${ }^{63}$ The first IV phase I/II clinical trials are currently being conducted in spinal muscular atrophy (SMA) (NCT02122952) and MPS IIIA (NCT02716246). Results of the intervention's potential beneficial effect on the CNS aspects of these diseases will demonstrate whether this approach could be envisaged for other LSDs. A significant is- sue in the transition to humans will be linked to the high doses of virus required to have a therapeutic effect in the CNS (i.e., AAV9 doses up to $3.3 \times 10^{14}$ GC/kg are proposed in the SMA clinical trial).

Significant progress has been made in global CNS targeting, using rAAV, with evidence of therapeutic potential for neuropathic LSD. Preclinical studies demonstrate that a variety of serotype and injection routes can be used to improve neuropathological and functional deficits. Phase I/II clinical trials of multiple intraparenchymal AAV injections showed the safety of this approach, which can delay the onset or progression of the disease. Studies using larger numbers of patients will be required to confirm these observations.

\section{Alzheimer's disease}

Key neuropathological hallmarks of $\mathrm{AD}$ are extracellular amyloid plaques produced from the metabolism of the amyloid precursor protein (APP) and intracellular accumulation of abnormally phosphorylated tau protein, a microtubule assembly protein, forming neurofibrillary tangles (NFTs). ${ }^{64-66}$ The mechanisms underlying these neuropathological changes remain unclear. There is today no treatment able to stop the progression of the disease. Several gene therapy strategies have been evaluated, targeting different pathways involved in $\mathrm{AD}$ physiopathology, some with encouraging results.

Strategies to reduce the amyloid accumulation by increasing amyloid-degrading proteases, such as neprilysin (NEP) and endothelin-converting enzyme (ECE), ${ }^{67}$ or by delivering anti-A $\beta$ singlechain antibody into the corticohippocampal regions of $\mathrm{AD}$ mice, using $\mathrm{AAV}$ vectors, were shown to decrease plaques and $\mathrm{A} \beta$ in the cortex and hippocampus of an $\mathrm{AD}$ mouse model ${ }^{68-70}$ with no sign of neurotoxicity. ${ }^{70}$

The nonamyloidogenic pathway ${ }^{71}$ of APP metabolism prevents the production of amyloid toxic forms and enables the release of the soluble APPs $\alpha$, which is thought to be responsible for the important physiological functions of APP. ${ }^{72}$ Loss of the neuroprotective APPs $\alpha$ could contribute to the development of $\mathrm{AD}$. APPs $\alpha$ levels are decreased in the CSF of patients with $\mathrm{AD}$, in both genetic and sporadic forms, which is correlated with poor memory. ${ }^{73,74} \mathrm{APPs} \alpha$ inhibits tau phosphorylation through glycogen synthase kinase $3 \beta$ (GSK3 $\beta$ ) modulation. ${ }^{75}$ Increasing the physiological APP pathway is thus an interesting strategy to treat $\mathrm{AD}$, and $\mathrm{APP} \alpha$ overexpression could alleviate $\mathrm{AD}$-related symptoms. APPs $\alpha$ overexpression by means of AAV in the hippocampal neurons of $\mathrm{AD}$ mice ${ }^{76}$ rescued spatial memory de- 
fects, restored synaptic plasticity and spine density, and decreased soluble $\mathrm{A} \beta$ and amyloid plaques. This was associated with microglial activation and amyloid plaque phagocytosis.

Neurotrophic factors are good candidates in neuroprotective strategies, but these factors may cause off-target adverse effects, necessitating a targeted delivery strategy to control their localization and spread in the brain. ${ }^{77}$ Nerve growth factor (NGF), which stimulates the function of basal forebrain cholinergic neurons undergoing early degeneration in $\mathrm{AD},{ }^{78}$ was evaluated in early disease onset in animal models. Encouraging preclinical data and the first clinical trial based on modified fibroblast implantation resulted in a phase I clinical trial in which NGF was administered to 10 patients, who received rAAV2-NGF into the basal forebrain region (NCT00087789). A dose escalation protocol was used: $1.2 \times 10^{10}$ to $1.2 \times 10^{11}$ vector particles ${ }^{79}$ (Table 1). The brains of patients, which were examined, exhibited a trophic response to NGF in the form of axonal sprouting toward the NGF source. Cholinergic neuronal hypertrophy occurred on the NGF-treated side. Activation of cellular signaling and functional markers was present in the two patients who underwent rAAV2-NGF gene transfer. An overall lower rate of cognitive decline and increased cortical glucose uptake were reported. A phase II multicenter, sham surgery-controlled trial of NGF in $\mathrm{AD}$ is ongoing in 49 patients with mild to moderate $\mathrm{AD}$, based on a single administration of AAV-NGF vector that encodes the gene for nerve growth factor (CERE-110) or an appropriate sham (placebo) surgery control treatment. ${ }^{80}$ Insulin-like growth factor (IGF)-2, which plays a critical role in memory consolidation in rodents, was administered via an AAV2 vector into the hippocampus of aged wild-type mice and in APP Tg2576 mice. IGF-2 expression enhanced memory, promoted dendritic spine formation in wild-type mice, decreased amyloid levels, and rescued behavioral deficits in $\mathrm{AD}$ mice, suggesting that IGF-2 may act as an $\mathrm{A} \beta$ scavenger. ${ }^{81}$

Increasing evidence demonstrates the role of inflammation in $\mathrm{AD}$. Antiinflammatory cytokine signaling may play an emerging role as neurotransmitters, neuromodulators, and neurohormones in the brain. Targeting the inflammatory pathway was thus evaluated, using interleukin (IL) delivery. Expression of IL-4 or IL-10 in the brain of $\mathrm{AD}$ mice resulted in reduced astro/microgliosis, reduced $\mathrm{A} \beta$ deposition, increased neurogenesis, and improved spatial learning. ${ }^{82,83}$

The role of lipid metabolism is increasingly evidenced in $\mathrm{AD}$. APOE, a regulator of lipoprotein metabolism in the CNS that plays several impor- tant roles such as cholesterol transport, neuroplasticity, and inflammation and $\mathrm{A} \beta$ clearance and aggregation $^{84}$ is the major risk factor for late-onset $\mathrm{AD}$. A gene transfer approach to bathe the cortex of amyloid plaque-bearing transgenic mice with APOE was used by injecting into the lateral ventricles of $\mathrm{AD}$ mice an $\mathrm{AAV}$ vector expressing the various human APOE alleles to transduce the ependymal layer. Human APOE proteins diffused into the CSF and interstitial fluid (ISF). Human APOE isoforms affected the concentrations of soluble oligomeric $\mathrm{A} \beta$ in the ISF, the pace of $\mathrm{A} \beta$ fibrillization and deposition, and the extent of periplaque neurotoxic effects. Increase in soluble $\mathrm{A} \beta$, exacerbation of synaptic loss, and an increased number of dystrophic neurites around each deposit were observed in $\mathrm{AD}$ mice receiving APOE4, whereas a relatively protective effect was observed with APOE2. These results suggest that therapeutic approaches aimed at decreasing APOE4 may be beneficial in $\mathrm{AD}{ }^{85}$

In $\mathrm{AD}$, altered cholesterol metabolism seems to play a pivotal role in the formation of amyloid plaques and in tau pathology. ${ }^{86}$ The major exportable form of brain cholesterol is 24(S)-hydroxycholesterol (24S-OHC) generated by the neuronal cholesterol 24-hydroxylase enzyme (CYP46A1). Overexpression of CYP46A1 by administering to the brain an AAV vector carrying CYP46A1 in rodent models of $\mathrm{AD}$ reduced the number of amyloid plaques and improved spatial memory in amyloid models, ${ }^{87}$ and improved cognitive deficits and impaired long-term depression and spine defects in mice with tauopathy ${ }^{88}$ suggesting that CYP46A1 is a relevant target for $\mathrm{AD}$.

All the approaches described have shown some preclinical efficacy in mouse models of $\mathrm{AD}$ and raised hopes for clinical applications in human patients. However, the main hurdle of gene therapy for $\mathrm{AD}$ is the diffusion of the lesions in the brain. $\mathrm{AD}$ impacts a number of anatomical subregions of the brain that are involved in learning and memory. $\mathrm{AAV}$-based gene therapy strategies for $\mathrm{AD}$ should thus rely on safe neurosurgical protocols able to target efficiently early-affected regions by means of improved delivery methods and use of serotypes with good diffusion properties (anterograde and retrograde transport). The development of modified AAV vectors able to efficiently cross the $\mathrm{BBB}$ should improve such strategies in future. ${ }^{1,89-92}$

\section{Parkinson's disease}

Many neuroprotective treatments have been developed for $\mathrm{PD}$, which is the second most common neurodegenerative disorder. In addition to deep 
brain stimulations and cell therapies, gene therapies have emerged as promising alternatives. For example, it has been shown that lysosomal hydrolase glucocerebrosidase activity is reduced in PD. Increasing it by gene transfer in mouse and rat models of PD showed neuroprotective effects against dopaminergic neuron degeneration. ${ }^{93}$ Protection of these dopaminergic neurons from Parkinson degenerative processes has also been shown by AAV-mediated overexpression of the transcription factors Nurr1 and Foxa2. ${ }^{94}$ As for other diseases such as epilepsy, the glial cell line-derived neurotrophic factor (GDNF) has been overexpressed in rats and monkeys with lesions of the dopamine system and showed amelioration of lesion-induced behavioral deficits. ${ }^{95,96}$ Nonhuman primates are indeed of interest to validate the clinical usefulness of AAV infusion in brain structures affected by PD such as striatum and putamen, ${ }^{97}$ and GDNF overexpression in the striatum and substantia nigra of marmoset monkeys showed behavioral and anatomical efficacy. ${ }^{98}$ Clinically relevant effects were also obtained in rhesus macaques, where GDNF overexpression promoted restoration of the dopaminergic system in these regions. ${ }^{99,100}$ Another strategy often used in gene therapies for $\mathrm{PD}$ consists in overexpressing the enzyme aromatic L-amino acid decarboxylase (AADC). Indeed, AADC is in charge of converting l-dopa, the main medication for $\mathrm{PD}$, to dopamine and is decreased in patients with PD. AAV-mediated overexpression of AADC showed $50 \%$ improvement in L-dopa responsiveness $^{101}$ and persistent results for at least 8 years. ${ }^{2}$ CERE-120, an AAV2 encoding neurturin (NTN), has been shown to protect dopaminergic neurons in preclinical studies. ${ }^{102,103}$ Injection of CERE-120 into the putamen alone or into both the putamen and substantia nigra in more than 100 people with PD (Table 1) showed no adverse effect for up to 5 years. ${ }^{104}$ However, efficacy results were modest with no significant improvement in primary outcome measures. ${ }^{105,106}$ To date, several clinical trials are ongoing to evaluate the safety and effectiveness of rAAV-GDNF or rAAV-AADC injection (Table 1). Because of the lack of efficacy of several drugs in phase III, such as creatine and ubiquinone, rAAVgene therapy for PD seems promising and could offer an interesting alternative.

\section{Huntington's disease}

$\mathrm{HD}$ is an autosomal dominant neurodegenerative disorder characterized by chorea, dystonia, progressive cognitive deterioration, and psychiatric disturbances evolving to dementia. The disease usually occurs in mid-life, followed by progressive aggravation of symptoms and death within 10-20 years. ${ }^{107,108}$ The genetic cause of the disease is a CAG (cytosine-adenine-guanine) triplet repeat expansion in the huntingtin gene (HTT) exceeding approximately 40 copies. Consequent polyglutamine expansion within the amino-terminal region of the HTT protein causes abnormal folding and accumulation of mutant HTT (mHTT) aggregates in cells. Neuroprotective agents have been tested in animal models to counter the toxic cellular effects of mHTT and improve neuronal survival. Brain-derived neurotrophic factor (BDNF), because of its functional interaction with HTT, has been evaluated in animal models of HD. GDNF family ligands (GFLs), that is, glial cell line-derived neurotrophic factor (GDNF), NTN, and ciliary neurotrophic factor (CNTF), have also been shown to support striatal neurons viability in vitro and in vivo. When administered via $\mathrm{rAAV} 2 / 1$ vector in mice with a quinolinic acid (QA) lesion, BDNF resulted in reduced motor impairment and striatal damage but toxicity was observed with weight loss and seizure activity, showing that lower concentrations of BDNF were necessary for neuroprotection without side effects. ${ }^{109}$ Single ICV delivery of BDNF and noggin to $\mathrm{rAAV4}$-BDNF/noggin-treated R6/2 mice resulted in delayed deterioration of motor function and increased survival. ${ }^{110}$ rAAV2-GDNF was also administered 2 weeks before a 3 -nitropropionic acid (3NP) lesion was induced in rats ${ }^{111}$ or in the HD mouse model (N171-82Q mice), ${ }^{112}$ resulting in improved performance and reduced neuronal atrophy. NTN, shown to protect striatal projection in excitotoxic models of HD, improved the performance of N171$82 \mathrm{Q}$ transgenic HD mice (Rotarod and clasping tests) after rAAV2-NTN (i.e., CERE-120) injection at 5 weeks of age but did not improve the weight of transgenic animals or their performance in the cognitive radial arm water maze task compared with control groups. ${ }^{113}$ CNTF was shown to support striatal neuron viability in vitro and in vivo. However, a study has shown that long-term expression of $\mathrm{CNTF}$, using the AAV2 vector, increases pathology in the brain of $\mathrm{R} 6 / 1$ transgenic mice. ${ }^{114}$ These results may be due to the high dose (rAAV2-CNTF at $2.7 \times 10^{12}$ vector genomes $[\mathrm{VG}] / \mathrm{ml}$, injected unilaterally or bilaterally). Even neurotrophic factors have already been safely used in clinical trials. Altogether these results indicate that caution must be used to establish doses when considering viral delivery of neurotrophic factors to protect against toxic effects of mHTT while avoiding potential side effects.

Direct therapeutic strategies have been developed to target the causative mHTT and reduce the synthesis of mutant protein and potentially pre- 
vent cellular damage. RNA interference strategies have shown that decreasing mHTT improves the HD phenotype in mouse and rat models. ${ }^{112,115-117}$ Using AAV vectors, various approaches have been developed using mHTT mRNA (single-nucleotide polymorphism)-specific microRNAs (miRNAs) and small hairpin RNAs (shRNAs) to block the formation of the mutant protein, and most recently, allelespecific blockage of transcription. Allele-specific methods selectively silencing mHTT are the most attractive option for HD gene therapy. However, this approach is challenging, because the mutant gene differs from the wild-type allele only by the number of CAG repeats, making both alleles vulnerable. Importantly, some toxic effects of shRNA in vivo were suppressed when placed into artificial miRNA expression systems, and miRNA-based approaches may provide more appropriate biological tools for expressing inhibitory RNAs in the brain. ${ }^{118}$ Repression of mHTT production was also tested with zinc finger proteins (ZFPs), using long artificial ZFP chains designed to bind longer CAG repeats more effectively than shorter repeats. This reduced chromosomal expression of the mutant gene. In vivo, striatal $\mathrm{rAAV} 2 / 1$ delivery in $\mathrm{R} 6 / 2$ mice revealed repression of $\mathrm{mHTT}$ in the brain, resulting in protein aggregate reduction and some improvement of motor and behavior performance, establishing a preliminary proof-of-principle for synthetic transcription factor repressors in the brain. ${ }^{119}$

Cholesterol metabolism is impaired in HD, and restoring cholesterol metabolism is thus an interesting therapeutic target. In $\mathrm{HD}$, a decrease in plasma $24 \mathrm{~S}-\mathrm{OHC}$, the oxysterol produced by brainspecific cholesterol 24-hydroxylase (CYP46A1), follows disease progression proportionally to motor and neuropsychiatric dysfunction and brain atrophy, as indicated by magnetic resonance imaging (MRI), together with lanosterol and lathosterol precursors (markers of cholesterol synthesis). Increased accumulation of cholesterol was observed in striatal neurons together with reduced levels of cholesterol metabolic precursors. CYP46A1 was shown to be decreased in the putamen of patients with HD and R6/2 mice. Moreover, striatal injection of AAVrh10-CYP46A1 vector in R6/2 mice decreased neuronal atrophy, decreased HTT aggregates, and improved motor deficits, as assessed by Rotarod and clasping behavioral tests. It also restored levels of cholesterol and lanosterol and increased levels of desmosterol that were found in vitro to protect striatal neurons expressing mHTT from death. ${ }^{120}$ These results strongly confirm that restoring cholesterol metabolism through CYP46A1 overexpression is a relevant therapeutic strategy in $\mathrm{HD}$.

\section{Amyotrophic lateral sclerosis}

ALS is a rapidly progressive neurodegenerative disorder affecting motor neurons in the spinal cord, brainstem, and cortex. All voluntary controlled muscles can be affected and most patients with ALS die from respiratory failure 2 to 5 years from the onset of symptoms. Ten to $20 \%$ of ALS cases are inherited. The most studied mutations linked to these familial forms are located in the $\mathrm{Cu} / \mathrm{Zn}$ superoxide dismutase 1 gene (SOD1). ${ }^{121}$ In SOD1transgenic animals, motor neurons degenerate and the animals die shortly after the onset of symptoms; these animals are often used as human-like ALS models. ${ }^{122}$ rAAV encoding IGF-1 was injected into the respiratory and motor limb muscles of SOD1 ${ }^{\mathrm{G} 93 \mathrm{~A}}$ mice, taking advantage or the vector retrograde transport from presynaptic terminals of projecting neurons to the projecting cell nucleus. Vector was transported up to motor neurons of the spinal cord, which allowed extended survival and a delay in motor decline. ${ }^{123}$ Lepore and colleagues used the same strategy but directed the injection into the lumbar spinal cord parenchyma of SOD1 ${ }^{\text {G93A }}$ mice. The long-term expression of IGF-1 was followed by delayed disease onset and extended survival but only in male SOD1 ${ }^{\text {G93A }}$ mice. ${ }^{124}$ The neuroprotective effect of IGF-1 in ALS was associated with decreased glial cell-mediated release of tumor necrosis factor- $\alpha$ and nitric oxide. ${ }^{125}$ The same group also achieved promising results with an rAAV injection into the lateral and fourth ventricles of SOD1 ${ }^{\mathrm{G} 93 \mathrm{~A}}$ mice. ${ }^{126}$ More recently, ICV or IT injection of AAV vector encoding microRNA against SOD1 improved disease outcome in SOD1 ${ }^{\mathrm{G} 93 \mathrm{~A}}$ mice, with preservation of muscle innervation and neuroprotection. ${ }^{127}$ The abundant evidence showing the importance of trophic factors to motor neurons as well as these preclinical results put forward a reliable strategy that could be brought to the clinic. In addition, IL-10 overexpression, using rAAV injection in the spinal cord of SOD $1^{\mathrm{G} 93 \mathrm{~A}}$ mice, produces an immune-modulatory effect with longer survival. ${ }^{128}$ More than $80 \%$ of ALS cases are sporadic and most patients do not carry the SOD1 mutation. Aizawa and colleagues showed in 2010 a molecular link between reduced adenosine deaminase acting on RNA 2 (ADAR2) activity and TAR DNA-binding protein (TDP-43) pathology, whose loss from the nucleus and positive cytoplasmic inclusions in motor neurons are characteristics of sporadic ALS. ${ }^{129}$ Yamashita and colleagues showed that AAV-ADAR2 delivery in motor neurons of ADAR2 knockout mice (AR2) enabled the restoration of ADAR2 activity and also prevented the progression of motor dysfunction and neuronal death. ${ }^{130}$ 
A few clinical trials using gene therapy in ALS have been started/completed (NCT00748501, NCT02039401, and NCT01041222) but none with rAAV. Despite this, positive results obtained in the above-mentioned preclinical studies may lead to novel promising studies in the clinic.

\section{Spinal muscular atrophy}

SMA is an autosomal recessive neurodegenerative disease leading to infant mortality caused by a mutation in the gene survival of motor neuron $(S M N)$. One approach to mitigating the effects of SMN loss of function is exogenous expression of its gene by introducing viral vectors into motor neurons. Several groups provided strong evidence for effective AAV-mediated gene therapy in SMA transgenic mice. AAV9-mediated gene delivery to replace the SMN protein on day 1 after birth in SMA mice resulted in elevated levels of SMN expression and extended survival. ${ }^{131}$ rAAV8-SMN was injected bilaterally into the lateral ventricles and the upper lumbar spinal cord of SMA mice, allowing improvements in behavioral tests indicating a functional neuromuscular junction and increased survival from 15 to 50 days. ${ }^{132}$ rAAV9 encoding a codon-optimized version of SMN injected into the facial vein on day 1 after birth resulted in a phenotypic correction, a significant increase in survival, ${ }^{133}$ complete correction of motor function, and a major increase in survival from 27 to more than 340 days. ${ }^{134}$

As for SMA, gene therapy has been used to rescue the phenotype of SMA with respiratory distress type 1 mice. This disease is caused by a mutation in the IGHMBP2 gene. rAAV9-IGHMB2 injection restored protein levels, rescued motor function, and increased the life span. ${ }^{135}$

As for ALS or neuropathic pain, intrathecal injection is a promising strategy and proof of concept to transduce motor neurons in juvenile farm pigs and monkeys has already been shown, ${ }^{136}$ supporting the use of gene therapy in clinical studies. To date, one clinical trial is actually ongoing to evaluate the safety and efficacy of intravenous delivery of self-complementary rAAV9-SMN as a potential treatment (Table 1).

\section{rAAV GENE THERAPY FOR OTHER DISORDERS AFFECTING THE NERVOUS SYSTEM}

\section{Epilepsy}

Epilepsy is characterized mainly by seizures caused by an imbalance between excitation and inhibition of electrical activities between neurons.
Even if the cause of most cases of epilepsy is unknown, some result from a brain lesion inducing mostly focal seizures, whereas others are associated with genetic defects resulting in generalized seizures. The identification of genetic cases highlighted several ion channels that helped researchers understand and investigate epilepsy, leading to the development of antiepileptic drugs targeting several ion channels. Seizures are often not sufficiently controlled, with current therapeutics, and new therapies are needed. ${ }^{137}$ rAAV gene therapy has been used to control seizures in several animal models, based mostly on the overexpression of neuropeptide Y (NPY). NPY, a 36-amino acid member of the pancreatic polypeptide family, is an endogenous modulator of epileptic activity. AAVmediated gene transfer to overexpress NPY in rats with electroencephalogram (EEG) seizures induced by intrahippocampal or intracerebroventricular kainic acid injection, allowed delayed seizure onset and a reduction in seizures by $50-75 \%, 8$ weeks after rAAV injection. ${ }^{138}$ Because NPY activates many receptor subtypes and may result in unwanted side effects, Foti and colleagues developed an rAAV expressing a truncated form of NPY that primarily activates the NPY Y2 receptor and obtained significantly prolonged latency of limbic seizures, 1 week after kainic acid injection. ${ }^{139} \mathrm{AAV}$ mediated gene transfer of NPY was also shown to safely improve anticonvulsant activity in kainic acid-treated rats without any glial activation or humoral immune response. ${ }^{140}$ Other transgenes have been used to attenuate seizures. Galanin, a neuropeptide with anticonvulsant properties combined with a secretory signal, was overexpressed with beneficial effects in kainic acid-treated rats. ${ }^{141}$ GDNF overexpression also leads to suppression of seizures in rat models of temporal lobe epilepsy. ${ }^{142}$ Downregulation of adenosine kinase (ADK) in mice via AAV-mediated RNA interference completely abolished spontaneous recurrent seizures in ADK-transgenic mice. ${ }^{143}$ Thus antiepileptogenic and antiseizure effects of these gene therapy approaches are promising via a decrease in excitatory signals or an increase in inhibitory signals. To date, no clinical trials with AAV-mediated gene transfer are currently ongoing, but all these preclinical studies support their application in the clinic.

\section{Neuropathic pain}

Even if neuropathic pain is often accompanied by tissue injury, it is a complex state that seems to have no obvious cause. Analgesic agents are recommended as first-line treatments, but analgesia has limitations such as a short half-life, lack of 
cellular specificity, and undesired potential off-site effects. Tissue injury, and thus the associated pain, is often chronic and localized and therefore suitable for the use of AAV-mediated gene therapies. A few studies have been carried out with AAV vectors to deliver several gene targets and treat neuropathic pain. In a model of sciatic nerve injury in Wistar rats, AAV vector overexpressing BDNF was injected into the dorsal horn of the spinal cord. One week after injection, rescue in several behavioral tasks was observed such as an alleviation of tactile allodynia and thermal hyperalgesia. ${ }^{144}$ Another approach used injection of rAAV expressing the $\mathrm{Ca}^{2+}$ channel-binding domain 3 (CBD3) into the lumbar dorsal root ganglion (DRG) in rats before the spared nerve injury (SNI). All injected rats presented a significant attenuation of behavioral changes in pain behavior such as hyperalgesia after touch with a pin or sensitivity to acetone stimulation. ${ }^{145}$ The knockdown of the voltage-gated sodium channel Nav1.3 via rAAV expressing shRNA was also evaluated in rats with SNI. rAAV injections were performed into the DRG; a partial attenuation of nerve injury-induced mechanical allodynia was observed. ${ }^{146}$ Intrathecal injection to treat diabetic neuropathic pain in diabetic Sprague Dawley rats also showed promising results with efficient transduction of DRGs and reduction of nociceptive hyperexcitability and neuropathic tactile allodynia associated with diabetic neuropathic pain. ${ }^{147}$ This method is rapid, less invasive than DRG injection, and clinically applicable. Intrathecal injection of AAV vector encoding shRNA against vanilloid receptor 1 (TRPV1) into the subarachnoid space of mice, 3 weeks after SNI surgery, showed significant attenuation of thermal hyperalgesia in response to $50^{\circ} \mathrm{C}$ heat stimulation observed from 7 days after treatment. ${ }^{148}$ These encouraging results should prompt evaluation in human patients with chronic/ diabetic neuropathic pain.

\section{PERSPECTIVE}

There is today a tremendous amount of preclinical data demonstrating the relevance and feasibility of AAV-based gene therapy to treat CNS disorders, not only for rare genetic diseases but also potentially for more common severe complex conditions. These have already led to a number of phase I/II clinical applications in human patients with encouraging results that should allow further developments to treat larger numbers of patients. Further steps will need to focus on the development of new tools improving the safety, efficacy and simplicity of gene delivery to the brain.

A potential immune response to AAV vectors is still a matter of debate. Direct intraparenchymal delivery uses considerably lower doses and is less likely to have an impact on a potential immune response. The development of IT, ICV, and eventually IV injection procedures will need much higher vector doses and will raise the question of immune reactions. After IV delivery, systemic exposure to high doses of AAV vectors can trigger the activation of $\mathrm{CD} 8^{+} \mathrm{T}$ cell responses directed against the viral capsid, in a dose-dependent manner, as observed in hemophilia clinical trials. ${ }^{149}$ Many approaches are currently being developed to address this crucial issue, immunological modulation in patients, detargeting vectors using specific promoters and miRNA sequences, ${ }^{150-154}$ and induction of immune tolerance. ${ }^{155-157}$

Improved efficacy of AAV vectors will benefit from the characterization of new serotypes that progressively emerge from the screening of AAV capsid libraries developed by DNA shuffling of existing AAV capsid genes. ${ }^{89,158-160}$ This should allow the design of customized tools, targeted to specific brain regions and for specific cell types. Intravenous delivery remains imperfect by the limited efficacy of $\mathrm{AAV}$ vectors to cross the BBB. The development of new tools to transiently increase permeability of the $\mathrm{BBB}$ and of new serotypes with higher crossing capacity ${ }^{90-92}$ will undoubtedly modify further strategies for safe and efficient CNS gene delivery. However, this will raise a consequent and challenging question concerning the ability to produce sufficient amounts of vectors for future clinical applications in a large number of patients. ${ }^{161}$

\section{ACKNOWLEDGMENTS}

The authors thank the Agence Nationale pour la Recherche (ANR, grant 13-BSV1-022-01), and the Fondation France Alzheimer and the Fondation pour la Recherche Médicale, for their support of research by N.C. on Huntington's disease (ANR) and Alzheimer's disease (FA and FRM). M.A. was supported by a grant from the DIM (Domaine d'Intérêt Majeur) Biotherapy Region Ile de France.

\section{AUTHOR DISCLOSURE}

M.H., S.P., and L.G. are full-time employees of Lysogene. N.C. is a founder and owner of founder equity in BrainVectis Therapeutics. M.A. declares no competing interests. 


\section{REFERENCES}

1. Choudhury SR, Hudry E, Maguire CA, et al. Viral vectors for therapy of neurologic diseases. Neuropharmacology 2016 (in press). DOI: 10.1016/ j.neuropharm.2016.02.013

2. Hadaczek P, Eberling JL, Pivirotto P, et al. Eight years of clinical improvement in MPTP-lesioned primates after gene therapy with AAV2-hAADC. Mol Ther 2010;18:1458-1461.

3. Mingozzi F, and High KA. Therapeutic in vivo gene transfer for genetic disease using AAV: progress and challenges. Nat Rev Genet 2011;12:341-355.

4. Rabinowitz JE, Rolling F, Li C, et al. Crosspackaging of a single adeno-associated virus (AAV) type 2 vector genome into multiple AAV serotypes enables transduction with broad specificity. J Virol 2002;76:791-801.

5. Burger C, Gorbatyuk OS, Velardo MJ, et al. Recombinant AAV viral vectors pseudotyped with viral capsids from serotypes 1, 2, and 5 display differential efficiency and cell tropism after delivery to different regions of the central nervous system. Mol Ther 2004;10:302-317.

6. Davidson BL, Stein CS, Heth JA, et al. Recombinant adeno-associated virus type 2, 4, and 5 vectors: transduction of variant cell types and regions in the mammalian central nervous system. Proc Natl Acad Sci U S A 2000;97:3428-3432.

7. Dodiya HB, Bjorklund T, Stansell J III, et al. Differential transduction following basal ganglia administration of distinct pseudotyped AAV capsid serotypes in nonhuman primates. Mol Ther 2010;18:579-587.

8. Klein RL, Dayton RD, Tatom JB, et al. AAV8, 9, Rh10, Rh43 vector gene transfer in the rat brain: effects of serotype, promoter and purification method. Mol Ther 2008;16:89-96.

9. Cearley CN, and Wolfe JH. Transduction characteristics of adeno-associated virus vectors expressing cap serotypes 7, 8, 9, and Rh10 in the mouse brain. Mol Ther 2006;13:528-537.

10. Furman JL, Sama DM, Gant JC, et al. Targeting astrocytes ameliorates neurologic changes in a mouse model of Alzheimer's disease. J Neurosci 2012;32:16129-16140.

11. Lawlor PA, Bland RJ, Mouravlev A, et al. Efficient gene delivery and selective transduction of glial cells in the mammalian brain by AAV serotypes isolated from nonhuman primates. Mol Ther 2009;17:1692-1702.

12. von Jonquieres $G$, Mersmann N, Klugmann CB, et al. Glial promoter selectivity following AAVdelivery to the immature brain. PLoS One 2013; 8:e65646.

13. Weller ML, Stone IM, Goss A, et al. Selective overexpression of excitatory amino acid transporter 2 (EAAT2) in astrocytes enhances neuroprotection from moderate but not severe hypoxiaischemia. Neuroscience 2008;155:1204-1211.
14. Simonato M, Bennett J, Boulis NM, et al. Progress in gene therapy for neurological disorders. Nat Rev Neurol 2013;9:277-291.

15. Leone P, Shera D, McPhee SW, et al. Long-term follow-up after gene therapy for canavan disease. Sci Transl Med 2012;4:165ra163.

16. Tardieu $M$, Zerah $M$, Husson $B$, et al. Intracerebral administration of AAV rh.10 carrying human SGSH and SUMF1 cDNAs in children with MPSIIIA disease: results of a phase I/II trial. Hum Gene Ther 2014;25:506-516.

17. Worgall S, Sondhi D, Hackett NR, et al. Treatment of late infantile neuronal ceroid lipofuscinosis by CNS administration of a serotype 2 adeno-associated virus expressing CLN2 cDNA. Hum Gene Ther 2008;19:463-474.

18. Gray SJ, Nagabhushan Kalburgi S, McCown TJ, et al. Global CNS gene delivery and evasion of anti-AAV-neutralizing antibodies by intrathecal AAV administration in non-human primates. Gene Ther 2013;20:450-459.

19. Meyer K, Ferraiuolo L, Schmelzer L, et al. Improving single injection CSF delivery of AAVgmediated gene therapy for SMA: a doseresponse study in mice and nonhuman primates. Mol Ther 2015;23:477-487.

20. Tse LV, Moller-Tank S, and Asokan A. Strategies to circumvent humoral immunity to adenoassociated viral vectors. Expert Opin Biol Ther 2015;15:845-855.

21. Bevan AK, Duque S, Foust KD, et al. Systemic gene delivery in large species for targeting spinal cord, brain, and peripheral tissues for pediatric disorders. Mol Ther 2011;19:1971-1980.

22. Foust $\mathrm{KD}$, Nurre $\mathrm{E}$, Montgomery $\mathrm{CL}$, et al. Intravascular AAV9 preferentially targets neonatal neurons and adult astrocytes. Nat Biotechnol 2009:27:59-65.

23. Gray SJ, Matagne V, Bachaboina L, et al. Preclinical differences of intravascular AAV9 delivery to neurons and glia: a comparative study of adult mice and nonhuman primates. Mol Ther 2011:19:1058-1069.

24. Zhang $H$, Yang B, Mu $X$, et al. Several rAAV vectors efficiently cross the blood-brain barrier and transduce neurons and astrocytes in the neonatal mouse central nervous system. Mol Ther 2011;19:1440-1448.

25. Cox TM, and Cachon-Gonzalez MB. The cellular pathology of lysosomal diseases. J Pathol 2012;226:241-254.

26. Fuller M, Meikle PJ, and Hopwood JJ. Epidemiology of lysosomal storage diseases: an overview. In: Fabry Disease: Perspectives from 5 Years of FOS. Mehta A, Beck M, SunderPlassmann G, eds. Oxford PharmaGenesis, Oxford. 2006; Chapter 2.
27. Bellettato CM, and Scarpa M. Pathophysiology of neuropathic lysosomal storage disorders. J Inherit Metab Dis 2010;33:347-362.

28. Fratantoni JC, Hall CW, and Neufeld EF. Hurler and Hunter syndromes: mutual correction of the defect in cultured fibroblasts. Science 1968;162: 570-572.

29. Chen F, Vitry $S$, Hocquemiller $M$, et al. $\alpha$-LIduronidase transport in neurites. Mol Genet Metab 2006;87:349-358.

30. Leinekugel $\mathrm{P}$, Michel $\mathrm{S}$, Conzelmann $\mathrm{E}$, et al. Quantitative correlation between the residual activity of $\beta$-hexosaminidase $\mathrm{A}$ and arylsulfatase $A$ and the severity of the resulting lysosomal storage disease. Hum Genet 1992;88:513-523.

31. Hemsley KM, and Hopwood JJ. Lessons learnt from animal models: pathophysiology of neuropathic Iysosomal storage disorders. J Inherit Metab Dis 2010;33:363-371.

32. Salegio EA, Samaranch L, Kells AP, et al. Axonal transport of adeno-associated viral vectors is serotype-dependent. Gene Ther 201;20:348-352.

33. Rosenberg JB, Sondhi D, Rubin DG, et al. Comparative efficacy and safety of multiple routes of direct CNS administration of adeno-associated virus gene transfer vector serotype rh.10 expressing the human arylsulfatase A cDNA to nonhuman primates. Hum Gene Ther Clin Dev 2014;25:164-177.

34. Treleaven CM, Tamsett TJ, Bu J, et al. Gene transfer to the CNS is efficacious in immuneprimed mice harboring physiologically relevant titers of anti-AAV antibodies. Mol Ther 2012; 20:1713-1723.

35. Cressant A, Desmaris N, Verot L, et al. Improved behavior and neuropathology in the mouse model of Sanfilippo type IIIB disease after adenoassociated virus-mediated gene transfer in the striatum. J Neurosci 2004;24:10229-10239.

36. Desmaris N, Verot L, Puech JP, et al. Prevention of neuropathology in the mouse model of Hurler syndrome. Ann Neurol 2004;56:68-76.

37. Ellinwood NM, Ausseil J, Desmaris N, et al. Safe, efficient, and reproducible gene therapy of the brain in the dog models of Sanfilippo and Hurler syndromes. Mol Ther 2011;19:251-259.

38. Baek RC, Broekman ML, Leroy SG, et al. AAV-mediated gene delivery in adult $\mathrm{GM}_{1}$ gangliosidosis mice corrects lysosomal storage in CNS and improves survival. PLoS One 2010; 5:e13468.

39. McCurdy VJ, Johnson AK, Gray-Edwards HL, et al. Sustained normalization of neurological disease after intracranial gene therapy in a feline model. Sci Transl Med 2014;6:231ra248.

40. Janson C, McPhee S, Bilaniuk L, et al. Clinical protocol: Gene therapy of Canavan disease: 
AAV-2 vector for neurosurgical delivery of aspartoacylase gene (ASPA) to the human brain. Hum Gene Ther 2002;13:1391-1412.

41. McPhee SW, Janson CG, Li C, et al. Immune responses to AAV in a phase I study for Canavan disease. J Gene Med 2006;8:577-588.

42. Passini MA, Watson DJ, Vite $\mathrm{CH}$, et al. Intraventricular brain injection of adenoassociated virus type 1 (AAV1) in neonatal mice results in complementary patterns of neuronal transduction to AAV2 and total long-term correction of storage lesions in the brains of $\beta$ glucuronidase-deficient mice. J Virol 2003;77: 7034-7040.

43. Broekman ML, Baek RC, Comer LA, et al. Complete correction of enzymatic deficiency and neurochemistry in the $\mathrm{GM}_{1}$-gangliosidosis mouse brain by neonatal adeno-associated virusmediated gene delivery. Mol Ther 2007;15:30-37.

44. Rafi MA, Zhi Rao H, Passini MA, et al. AAVmediated expression of galactocerebrosidase in brain results in attenuated symptoms and extended life span in murine models of globoid cell leukodystrophy. Mol Ther 2005;11:734-744.

45. Fraldi A, Hemsley K, Crawley A, et al. Functional correction of CNS lesions in an MPS-IIIA mouse model by intracerebral AAV-mediated delivery of sulfamidase and SUMF1 genes. Hum Mol Genet 2007:16:2693-2702.

46. Liu G, Martins I, Wemmie JA, et al. Functional correction of CNS phenotypes in a lysosomal storage disease model using adeno-associated virus type 4 vectors. J Neurosci 2005;25:9321-9327.

47. Katz ML, Tecedor L, Chen Y, et al. AAV gene transfer delays disease onset in a TPP1-deficient canine model of the late infantile form of Batten disease. Sci Transl Med 2015;7:313ra180.

48. Chauhan AN, and Lewis PD. A quantitative study of cell proliferation in ependyma and choroid plexus in the postnatal rat brain. Neuropathol Appl Neurobiol 1979;5:303-309.

49. Haurigot V, Marco S, Ribera A, et al. Whole body correction of mucopolysaccharidosis IIIA by intracerebrospinal fluid gene therapy. J Clin Invest 2013;123:3254-3271.

50. Ribera A, Haurigot V, Garcia $M$, et al. Biochemical, histological and functional correction of mucopolysaccharidosis type IIIB by intracerebrospinal fluid gene therapy. Hum $\mathrm{Mol}$ Genet 2015;24:2078-2095.

51. Yoon SY, Bagel JH, O'Donnell PA, et al. Clinical Improvement of $\alpha$-mannosidosis cat following a single cisterna magna infusion of AAV1. Mol Ther 2016;24:26-33.

52. Gurda BL, De Guilhem De Lataillade A, Bell P, et al. Evaluation of AAV-mediated gene therapy for central nervous system disease in canine mucopolysaccharidosis VII. Mol Ther 2016;24: 206-216.

53. Hinderer C, Bell P, Gurda BL, et al. Intrathecal gene therapy corrects CNS pathology in a feline model of mucopolysaccharidosis I. Mol Ther 2014:22:2018-2027.

54. Elliger SS, Elliger CA, Aguilar CP, et al. Elimination of lysosomal storage in brains of MPS VII mice treated by intrathecal administration of an adeno-associated virus vector. Gene Ther 1999; 6:1175-1178.

55. Watson G, Bastacky J, Belichenko P, et al. Intrathecal administration of AAV vectors for the treatment of lysosomal storage in the brains of MPS I mice. Gene Ther 2006;13:917-925.

56. Yang B, Li S, Wang H, et al. Global CNS transduction of adult mice by intravenously delivered rAAVrh.8 and rAAVrh.10 and nonhuman primates by rAAVrh.10. Mol Ther 2014;22:1299-1309.

57. Miyake N, Miyake K, Asakawa N, et al. Longterm correction of biochemical and neurological abnormalities in MLD mice model by neonatal systemic injection of an AAV serotype 9 vector. Gene Ther 2014;21:427-433.

58. Rafi MA, Rao HZ, Luzi $P$, et al. Intravenous injection of AAVrh10-GALC after the neonatal period in twitcher mice results in significant expression in the central and peripheral nervous systems and improvement of clinical features. Mol Genet Metab 2015;114:459-466.

59. Naughton BJ, Duncan FJ, Murrey D, et al. Amyloidosis, synucleinopathy, and prion encephalopathy in a neuropathic lysosomal storage disease: the CNS-biomarker potential of peripheral blood. PLoS One 2013;8:e80142.

60. Ruzo A, Marco S, Garcia M, et al. Correction of pathological accumulation of glycosaminoglycans in CNS and peripheral tissues of MPSIIIA mice through systemic AAV9 gene transfer. Hum Gene Ther 2012;23:1237-1246.

61. Weismann CM, Ferreira J, Keeler AM, et al. Systemic AAV9 gene transfer in adult $\mathrm{GM}_{1}$ gangliosidosis mice reduces lysosomal storage in CNS and extends lifespan. Hum Mol Genet 2015;24:4353-4364.

62. Walia JS, Altaleb N, Bello A, et al. Long-term correction of Sandhoff disease following intravenous delivery of rAAV9 to mouse neonates. Mol Ther 2015;23:414-422.

63. Chen YH, Claflin K, Geoghegan JC, et al. Sialic acid deposition impairs the utility of AAVg, but not peptide-modified AAVs for brain gene therapy in a mouse model of lysosomal storage disease. Mol Ther 2012;20:1393-1399.

64. Hardy J, and Allsop D. Amyloid deposition as the central event in the aetiology of Alzheimer's disease. Trends Pharmacol Sci 1991;12: 383-388.

65. Hardy J, Bogdanovic N, Winblad B, et al. Pathways to Alzheimer's disease. J Intern Med 2014;275:296-303

66. Selkoe DJ. Alzheimer's disease: genes, proteins, and therapy. Physiol Rev 2001;81:741-766.

67. Miners JS, Barua $N$, Kehoe $P G$, et al. $A \beta$ degrading enzymes: potential for treatment of
Alzheimer disease. J Neuropathol Exp Neurol 2011:70:944-959.

68. Carty N, Nash KR, Brownlow M, et al. Intracranial injection of AAV expressing NEP but not IDE reduces amyloid pathology in APP+PS1 transgenic mice. PLoS One 2013;8:e59626.

69. Carty NC, Nash K, Lee D, et al. Adenoassociated viral (AAV) serotype 5 vector mediated gene delivery of endothelin-converting enzyme reduces $A \beta$ deposits in APP + PS1 transgenic mice. Mol Ther 2008;16:1580-1586.

70. Fukuchi K, Tahara K, Kim HD, et al. Anti-A $\beta$ single-chain antibody delivery via adenoassociated virus for treatment of Alzheimer's disease. Neurobiol Dis 2006;23:502-511.

71. Zhang YW, Thompson R, Zhang $H$, et al. APP processing in Alzheimer's disease. Mol Brain 2011;4:3.

72. Weyer SW, Zagrebelsky M, Herrmann U, et al. Comparative analysis of single and combined APP/ APLP knockouts reveals reduced spine density in APP-KO mice that is prevented by APPs $\alpha$ expression. Acta Neuropathol Commun 2014;2:36.

73. Endres K, Fahrenholz F. Regulation of $\alpha$ secretase ADAM10 expression and activity. Exp Brain Res 2012;217:343-352

74. Fahrenholz F. $\alpha$-Secretase as a therapeutic target. Curr Alzheimer Res 2007;4:412-417.

75. Deng J, Habib A, Obregon DF, et al. Soluble amyloid precursor protein $\alpha$ inhibits tau phosphorylation through modulation of GSK3 $\beta$ signaling pathway. J Neurochem 2015;135:630-637.

76. Fol R, Braudeau J, Ludewig S, et al. Viral gene transfer of APPs $\alpha$ rescues synaptic failure in an Alzheimer's disease mouse model. Acta Neuropathol 2016;131:247-266.

77. Malkki H. Alzheimer disease: NGF gene therapy activates neurons in the $A D$ patient brain. Nat Rev Neurol 2015;11:548.

78. Kordower JH, Winn SR, Liu YT, et al. The aged monkey basal forebrain: rescue and sprouting of axotomized basal forebrain neurons after grafts of encapsulated cells secreting human nerve growth factor. Proc Natl Acad Sci U S A 1994 91:10898-10902.

79. Rafii MS, Baumann TL, Bakay RA, et al. A phase 1 study of stereotactic gene delivery of AAV2NGF for Alzheimer's disease. Alzheimers Dement 2014;10:571-581.

80. Tuszynski MH, Yang JH, Barba D, et al. Nerve growth factor gene therapy: activation of neuronal responses in Alzheimer disease. JAMA Neurol 2015;72:1139-1147.

81. Pascual-Lucas M, Viana da Silva S, Di Scala M, et al. Insulin-like growth factor 2 reverses memory and synaptic deficits in APP transgenic mice. EMBO Mol Med 2014;6:1246-1262.

82. Kiyota T, Ingraham KL, Swan RJ, et al. AAV serotype 2/1-mediated gene delivery of antiinflammatory interleukin-10 enhances neurogen- 
esis and cognitive function in APP+PS1 mice. Gene Ther 2012:19:724-733.

83. Kiyota T, Okuyama S, Swan RJ, et al. CNS expression of anti-inflammatory cytokine interleukin4 attenuates Alzheimer's disease-like pathogenesis in APP+PS1 bigenic mice. FASEB J 2010;24: 3093-3102.

84. Spinney L. Alzheimer's disease: the forgetting gene. Nature 2014;510:26-28.

85. Hudry E, Dashkoff J, Roe AD, et al. Gene transfer of human ApoE isoforms results in differential modulation of amyloid deposition and neurotoxicity in mouse brain. Sci Transl Med 2013;5:212ra161.

86. Ghribi 0. Potential mechanisms linking cholesterol to Alzheimer's disease-like pathology in rabbit brain, hippocampal organotypic slices, and skeletal muscle. J Alzheimers Dis 2008;15:673684.

87. Hudry E, Van Dam D, Kulik W, et al. Adenoassociated virus gene therapy with cholesterol 24-hydroxylase reduces the amyloid pathology before or after the onset of amyloid plaques in mouse models of Alzheimer's disease. Mol Ther 2010;18:44-53.

88. Burlot MA, Braudeau J, Michaelsen-Preusse K, et al. Cholesterol 24-hydroxylase defect is implicated in memory impairments associated with Alzheimer-like tau pathology. Hum Mol Genet 2015;24:5965-5976.

89. Castle MJ, Turunen HT, Vandenberghe LH, et al. Controlling AAV tropism in the nervous system with natural and engineered capsids. Methods Mol Biol 2016;1382:133-149.

90. Deverman BE, Pravdo PL, Simpson BP, et al. Credependent selection yields AAV variants for widespread gene transfer to the adult brain. Nat Biotechnol 2016;34:204-209.

91. Choudhury SR, Fitzpatrick Z, Harris AF, et al. In vivo selection yields AAV-B1 capsid for CNS and muscle gene therapy. Mol Ther 2016 (in press). DOI: 10.1038/mt.2016.84

92. Choudhury SR, Harris AF, Cabral DJ, et al. Widespread central nervous system gene transfer and silencing after systemic delivery of novel AAV-AS vector. Mol Ther 2016;24:726735

93. Rocha EM, Smith GA, Park E, et al. Glucocerebrosidase gene therapy prevents $\alpha$-synucleinopathy of midbrain dopamine neurons. Neurobiol Dis 2015; 82:495-503.

94. Oh SM, Chang MY, Song JJ, et al. Combined Nurr1 and Foxa2 roles in the therapy of Parkinson's disease. EMBO Mol Med 2015;7:510-525.

95. Kearns CM, and Gash DM. GDNF protects nigral dopamine neurons against 6-hydroxydopamine in vivo. Brain Res 1995;672:104-111.

96. Kirik D, Rosenblad C, Burger C, et al. Parkinsonlike neurodegeneration induced by targeted overexpression of $\alpha$-synuclein in the nigrostriatal system. J Neurosci 2002;22:2780-2791.
97. Sanftner LM, Sommer JM, Suzuki BM, et al. AAV2-mediated gene delivery to monkey putamen: evaluation of an infusion device and delivery parameters. Exp Neurol 2005;194:476-483.

98. Eslamboli A, Cummings RM, Ridley RM, et al. Recombinant adeno-associated viral vector (rAAV) delivery of GDNF provides protection against 6-OHDA lesion in the common marmoset monkey (Callithrix jacchus). Exp Neurol 2003; 184:536-548.

99. Johnston LC, Eberling J, Pivirotto P, et al. Clinically relevant effects of convectionenhanced delivery of AAV2-GDNF on the dopaminergic nigrostriatal pathway in aged rhesus monkeys. Hum Gene Ther 2009;20:497-510.

100. Kells AP, Eberling J, Su X, et al. Regeneration of the MPTP-lesioned dopaminergic system after convection-enhanced delivery of AAV2-GDNF. J Neurosci 2010;30:9567-9577.

101. Forsayeth JR, Eberling JL, Sanftner LM, et al. A dose-ranging study of AAV-hAADC therapy in Parkinsonian monkeys. Mol Ther 2006;14:571577.

102. Gasmi M, Brandon EP, Herzog CD, et al. AAV2mediated delivery of human neurturin to the rat nigrostriatal system: long-term efficacy and tolerability of CERE-120 for Parkinson's disease. Neurobiol Dis 2007;27:67-76.

103. Herzog CD, Dass B, Holden JE, et al. Striatal delivery of CERE-120, an AAV2 vector encoding human neurturin, enhances activity of the dopaminergic nigrostriatal system in aged monkeys. Mov Disord 2007;22:1124-1132.

104. Marks WJ Jr, Baumann TL, and Bartus RT. Longterm safety of patients with Parkinson's disease receiving rAAV2-neurturin (CERE-120) gene transfer. Hum Gene Ther 2016;27:522-527.

105. Herzog CD, Brown L, Kruegel BR, et al. Enhanced neurotrophic distribution, cell signaling and neuroprotection following substantia nigral versus striatal delivery of AAV2-NRTN (CERE-120). Neurobiol Dis 2013;58:38-48.

106. Marks WJ Jr, Bartus RT, Siffert J, et al. Gene delivery of AAV2-neurturin for Parkinson's disease: a double-blind, randomised, controlled trial. Lancet Neurol 2010;9:1164-1172.

107. Vonsattel JP, and DiFiglia M. Huntington disease. J Neuropathol Exp Neurol 1998;57:369384.

108. Vonsattel JP, Myers RH, Stevens TJ, et al. Neuropathological classification of Huntington's disease. J Neuropathol Exp Neurol 1985;44:559577 .

109. Kells AP, Henry RA, and Connor B. AAV-BDNF mediated attenuation of quinolinic acid-induced neuropathology and motor function impairment. Gene Ther 2008;15:966-977.

110. Benraiss A, Toner MJ, Xu O, et al. Sustained mobilization of endogenous neural progenitors delays disease progression in a transgenic model of Huntington's disease. Cell Stem Cell 2013; 12:787-799.
111. McBride JL, During MJ, Wuu J, et al. Structural and functional neuroprotection in a rat model of Huntington's disease by viral gene transfer of GDNF. Exp Neurol 2003;181:213-223.

112. McBride JL, Ramaswamy S, Gasmi M, et al. Viral delivery of glial cell line-derived neurotrophic factor improves behavior and protects striatal neurons in a mouse model of Huntington's disease. Proc Natl Acad Sci U S A 2006;103:93459350.

113. Ramaswamy S, McBride JL, Han I, et al. Intrastriatal CERE-120 (AAV-neurturin) protects striatal and cortical neurons and delays motor deficits in a transgenic mouse model of Huntington's disease. Neurobiol Dis 2009;34: 40-50.

114. Denovan-Wright EM, Attis M, Rodriguez-Lebron $E$, et al. Sustained striatal ciliary neurotrophic factor expression negatively affects behavior and gene expression in normal and R6/1 mice. $J$ Neurosci Res 2008:86:1748-1757.

115. Franich NR, Fitzsimons HL, Fong DM, et al. AAV vector-mediated RNAi of mutant huntingtin expression is neuroprotective in a novel genetic rat model of Huntington's disease. Mol Ther 2008; 16:947-956.

116. Harper SQ, Staber PD, He X, et al. RNA interference improves motor and neuropathological abnormalities in a Huntington's disease mouse model. Proc Natl Acad Sci U S A 2005;102:58205825 .

117. Stanek LM, Sardi SP, Mastis B, et al. Silencing mutant huntingtin by adeno-associated virusmediated RNA interference ameliorates disease manifestations in the YAC128 mouse model of Huntington's disease. Hum Gene Ther 2014;25: 461-474.

118. McBride JL, Boudreau RL, Harper SQ, et al. Artificial miRNAs mitigate shRNA-mediated toxicity in the brain: implications for the therapeutic development of RNAi. Proc Natl Acad Sci U S A 2008; 105:5868-5873.

119. Garriga-Canut M, Agustin-Pavon C, Herrmann F, et al. Synthetic zinc finger repressors reduce mutant huntingtin expression in the brain of R6/ 2 mice. Proc Natl Acad Sci U S A 2012;109: E3136-E3145.

120. Boussicault L, Alves S, Lamaziere A, et al. CYP46A1, the rate-limiting enzyme for cholesterol degradation, is neuroprotective in Huntington's disease. Brain 2016;139:953-970.

121. Kunst $C B$. Complex genetics of amyotrophic lateral sclerosis. Am J Hum Genet 2004;75:933947.

122. Higgins $C M$, Jung $C$, and $X u Z$. ALS-associated mutant SOD1G93A causes mitochondrial vacuolation by expansion of the intermembrane space and by involvement of SOD1 aggregation and peroxisomes. BMC Neurosci 2003;4:16.

123. Kaspar BK, Llado J, Sherkat N, et al. Retrograde viral delivery of IGF-1 prolongs survival in a mouse ALS model. Science 2003;301:839-842. 
124. Lepore AC, Haenggeli C, Gasmi M, et al. Intraparenchymal spinal cord delivery of adenoassociated virus IGF-1 is protective in the SOD1G93A model of ALS. Brain Res 2007;1185: 256-265.

125. Dodge JC, Haidet AM, Yang W, et al. Delivery of AAV-IGF-1 to the CNS extends survival in ALS mice through modification of aberrant glial cell activity. Mol Ther 2008;16:1056-1064.

126. Dodge JC, Treleaven CM, Fidler JA, et al. AAV4mediated expression of IGF-1 and VEGF within cellular components of the ventricular system improves survival outcome in familial ALS mice. Mol Ther 2010;18:2075-2084.

127. Dirren E, Aebischer J, Rochat C, et al. SOD1 silencing in motoneurons or glia rescues neuromuscular function in ALS mice. Ann Clin Transl Neurol 2015;2:167-184.

128. Ayers JI, Fromholt $S$, Sinyavskaya 0 , et al. Widespread and efficient transduction of spinal cord and brain following neonatal AAV injection and potential disease modifying effect in ALS mice. Mol Ther 2015;23:53-62.

129. Aizawa H, Sawada J, Hideyama T, et al. TDP-43 pathology in sporadic ALS occurs in motor neurons lacking the RNA editing enzyme ADAR2. Acta Neuropathol 2010;120:75-84.

130. Yamashita T, Chai HL, Teramoto S, et al. Rescue of amyotrophic lateral sclerosis phenotype in a mouse model by intravenous AAVg-ADAR2 delivery to motor neurons. EMBO Mol Med 2013;5: 1710-1719.

131. Foust KD, Wang X, McGovern VL, et al. Rescue of the spinal muscular atrophy phenotype in a mouse model by early postnatal delivery of SMN. Nat Biotechnol 2010;28:271-274.

132. Passini MA, Bu J, Roskelley EM, et al. CNStargeted gene therapy improves survival and motor function in a mouse model of spinal muscular atrophy. J Clin Invest 2010;120:12531264.

133. Valori CF, Ning K, Wyles M, et al. Systemic delivery of scAAV9 expressing SMN prolongs survival in a model of spinal muscular atrophy. Sci Transl Med 2010;2:35ra42.

134. Dominguez $\mathrm{E}$, Marais T, Chatauret $\mathrm{N}$, et al. Intravenous scAAV9 delivery of a codon-optimized SMN1 sequence rescues SMA mice. Hum Mol Genet 2011;20:681-693.

135. Nizzardo M, Simone C, Rizzo F, et al. Gene therapy rescues disease phenotype in a spinal muscular atrophy with respiratory distress type 1 (SMARD1) mouse model. Sci Adv 2015;1:e1500078.

136. Passini MA, Bu J, Richards AM, et al. Translational fidelity of intrathecal delivery of selfcomplementary AAV9-survival motor neuron 1 for spinal muscular atrophy. Hum Gene Ther 2014;25:619-630.

137. Galanopoulou AS, Buckmaster PS, Staley KJ, et al. Identification of new epilepsy treatments: issues in preclinical methodology. Epilepsia 2012:53:571-582.
138. Richichi C, Lin EJ, Stefanin D, et al. Anticonvulsant and antiepileptogenic effects mediated by adenoassociated virus vector neuropeptide $Y$ expression in the rat hippocampus. $J$ Neurosci 2004;24:3051-3059.

139. Foti S, Haberman RP, Samulski RJ, et al. Adenoassociated virus-mediated expression and constitutive secretion of NPY or NPY13-36 suppresses seizure activity in vivo. Gene Ther 2007;14:15341536.

140. Noe F, Vaghi V, Balducci C, et al. Anticonvulsant effects and behavioural outcomes of rAAV serotype 1 vector-mediated neuropeptide $Y$ overexpression in rat hippocampus. Gene Ther 2010; 17:643-652

141. Haberman RP, Samulski RJ, and McCown TJ. Attenuation of seizures and neuronal death by adeno-associated virus vector galanin expression and secretion. Nat Med 2003;9:1076-1080.

142. Kanter-Schlifke I, Georgievska B, Kirik D, et al. Seizure suppression by GDNF gene therapy in animal models of epilepsy. Mol Ther 2007;15: 1106-1113.

143. Theofilas P, Brar S, Stewart KA, et al. Adenosine kinase as a target for therapeutic antisense strategies in epilepsy. Epilepsia 2011;52:589-601.

144. Eaton MJ, Blits B, Ruitenberg MJ, et al. Amelioration of chronic neuropathic pain after partial nerve injury by adeno-associated viral (AAV) vector-mediated over-expression of BDNF in the rat spinal cord. Gene Ther 2002:9:1387-1395.

145. Fischer G, Pan B, Vilceanu D, et al. Sustained relief of neuropathic pain by AAV-targeted expression of CBD3 peptide in rat dorsal root ganglion. Gene Ther 2014;21:44-51.

146. Samad OA, Tan AM, Cheng $X$, et al. Virusmediated shRNA knockdown of $\mathrm{Na}(\mathrm{v}) 1.3$ in rat dorsal root ganglion attenuates nerve injuryinduced neuropathic pain. Mol Ther 2013;21:4956.

147. Tan AM, Samad OA, Dib-Hajj SD, et al. Virusmediated knockdown of Nav1.3 in dorsal root ganglia of STZ-induced diabetic rats alleviates tactile allodynia. Mol Med 2015;21:544-552.

148. Hirai $T$, Enomoto $M$, Kaburagi $H$, et al. Intrathecal AAV serotype 9-mediated delivery of shRNA against TRPV1 attenuates thermal hyperalgesia in a mouse model of peripheral nerve injury. Mol Ther 2014;22:409-419.

149. Mingozzi $F$, and High KA. Immune responses to AAV in clinical trials. Curr Gene Ther 2011;11: 321-330.

150. Borel F, Kay MA, and Mueller C. Recombinant $A A V$ as a platform for translating the therapeutic potential of RNA interference. Mol Ther 2014; 22:692-701.

151. Geisler A, Jungmann A, Kurreck J, et al. microRNA122-regulated transgene expression increases specificity of cardiac gene transfer upon intravenous delivery of AAV9 vectors. Gene Ther 2011;18:199-209.
152. Majowicz A, Maczuga P, Kwikkers KL, et al. Mir$142-3 p$ target sequences reduce transgenedirected immunogenicity following intramuscular adeno-associated virus 1 vector-mediated gene delivery. J Gene Med 2013:15:219-232.

153. Qiao C, Yuan Z, Li J, et al. Liver-specific microRNA-122 target sequences incorporated in AAV vectors efficiently inhibits transgene expression in the liver. Gene Ther 2011;18:403-410.

154. Xie J, Xie 0 , Zhang $H$, et al. MicroRNAregulated, systemically delivered rAAV9: a step closer to CNS-restricted transgene expression. Mol Ther 2011;19:526-535.

155. Doerfler PA, Todd AG, Clement N, et al. Copackaged AAV9 vectors promote simultaneous immune tolerance and phenotypic correction of Pompe disease. Hum Gene Ther 2016;27:43-59.

156. Hinderer C, Bell P, Louboutin JP, et al. Neonatal systemic AAV induces tolerance to CNS gene therapy in MPS I dogs and nonhuman primates. Mol Ther 2015;23:1298-1307.

157. Mingozzi F, and Buning H. Adeno-associated viral vectors at the frontier between tolerance and immunity. Front Immunol 2015;6:120.

158. Grimm D, Lee JS, Wang L, et al. In vitro and in vivo gene therapy vector evolution via multispecies interbreeding and retargeting of adenoassociated viruses. J Virol 2008;82:5887-5911.

159. Koerber JT, Jang JH, and Schaffer DV. DNA shuffling of adeno-associated virus yields functionally diverse viral progeny. Mol Ther 2008; 16:1703-1709

160. Maheshri N, Koerber JT, Kaspar BK, et al. Directed evolution of adeno-associated virus yields enhanced gene delivery vectors. Nat Biotechnol 2006;24:198-204.

161. Grieger JC, and Samulski RJ. Adeno-associated virus vectorology, manufacturing, and clinical applications. Methods Enzymol 2012;507:229-254.

162. LeWitt PA, Rezai AR, Leehey MA, et al. AAV2GAD gene therapy for advanced Parkinson's disease: a double-blind, sham-surgery controlled, randomised trial. Lancet Neurol 2011;10:309-319.

163. Mittermeyer G, Christine CW, Rosenbluth KH, et al. Long-term evaluation of a phase 1 study of AADC gene therapy for Parkinson's disease. Hum Gene Ther 2012;23:377-381.

164. Marks WJ Jr, Ostrem JL, Verhagen L, et al. Safety and tolerability of intraputaminal delivery of CERE-120 (adeno-associated virus serotype 2neurturin) to patients with idiopathic Parkinson's disease: an open-label, phase I trial. Lancet Neurol 2008;7:400-408.

165. Bartus RT, Baumann TL, Siffert J, et al. Safety/ feasibility of targeting the substantia nigra with AAV2-neurturin in Parkinson patients. Neurology 2013;80:1698-1701

166. Broekman ML, Tierney LA, Benn C, et al. Mechanisms of distribution of mouse $\beta$-galactosidase in the adult $\mathrm{GM}_{1}$-gangliosidosis brain. Gene Ther 2009:16:303-308. 
167. Sargeant TJ, Wang S, Bradley J, et al. Adenoassociated virus-mediated expression of $\beta$ hexosaminidase prevents neuronal loss in the Sandhoff mouse brain. Hum Mol Genet 2011; 20:4371-4380.

168. Lin D, Fantz CR, Levy B, et al. AAV2/5 vector expressing galactocerebrosidase ameliorates CNS disease in the murine model of globoid-cell leukodystrophy more efficiently than AAV2. Mol Ther 2005;12:422-430.

169. Macauley SL, Wong AM, Shyng C, et al. An antineuroinflammatory that targets dysregulated glia enhances the efficacy of CNS-directed gene therapy in murine infantile neuronal ceroid lipofuscinosis. J Neurosci 2014;34:13077-13082.

170. Sondhi D, Scott EC, Chen A, et al. Partial correction of the CNS Iysosomal storage defect in a mouse model of juvenile neuronal ceroid lipofuscinosis by neonatal CNS administration of an adeno-associated virus serotype rh.10 vector expressing the human CLN3 gene. Hum Gene Ther 2014;25:223-239.

171. Passini MA, Dodge JC, Bu J, et al. Intracranial delivery of CLN2 reduces brain pathology in a mouse model of classical late infantile neuronal ceroid lipofuscinosis. J Neurosci 2006;26:1334-1342.

172. Winner LK, Beard H, Hassiotis S, et al. A preclinical study evaluating AAVrh10-based gene therapy for Sanfilippo syndrome. Hum Gene Ther 2016;27:363-375

173. Heldermon CD, Ohlemiller KK, Herzog ED, et al. Therapeutic efficacy of bone marrow transplant, intracranial AAV-mediated gene therapy, or both in the mouse model of MPS IIIB. Mol Ther 2010;18:873-880.

174. Heldermon CD, Oin EY, Ohlemiller KK, et al. Disease correction by combined neonatal intracranial AAV and systemic lentiviral gene therapy in Sanfilippo syndrome type B mice. Gene Ther 2013;20:913-921.

175. Liu G, Chen YH, He X, et al. Adeno-associated virus type 5 reduces learning deficits and restores glutamate receptor subunit levels in MPS VII mice CNS. Mol Ther 2007;15:242-247.

176. Cearley $\mathrm{CN}$, and Wolfe JH. A single injection of an adeno-associated virus vector into nuclei with divergent connections results in widespread vector distribution in the brain and global correction of a neurogenetic disease. $J$ Neurosci 2007;27:9928-9940.

177. Piguet F, Sondhi D, Piraud M, et al. Correction of brain oligodendrocytes by AAVrh.10 intracerebral gene therapy in metachromatic leukodystrophy mice. Hum Gene Ther 2012;23:903-914.

178. Passini MA, Bu J, Fidler JA, et al. Combination brain and systemic injections of AAV provide maximal functional and survival benefits in the Niemann-Pick mouse. Proc Natl Acad Sci U S A 2007:104:9505-9510.

179. Bradbury AM, Cochran JN, McCurdy VJ, et al. Therapeutic response in feline Sandhoff disease despite immunity to intracranial gene therapy. Mol Ther 2013:21:1306-1315.

180. Colle MA, Piguet F, Bertrand L, et al. Efficient intracerebral delivery of AAV5 vector encoding human ARSA in non-human primate. Hum Mol Genet 2010;19:147-158.

181. Zerah M, Piguet F, Colle MA, et al. Intracerebral gene therapy using AAVrh.10-hARSA recombinant vector to treat patients with early-onset forms of metachromatic leukodystrophy: preclinical feasibility and safety assessments in non-human primates. Hum Gene Ther Clin Dev 2015;26:113-124.

182. Sondhi $D$, Johnson $L$, De B, et al. Long term expression and safety of administration of AAVrh.10hCLN2 to the brain of rats and nonhuman primates for the treatment of late infantile neuronal lipofuscinosis. Hum Gene Ther Methods 2012;23:324-335.

183. Ciron C, Cressant A, Roux F, et al. Human $\alpha$ iduronidase gene transfer mediated by adenoassociated virus types 1,2 , and 5 in the brain of nonhuman primates: vector diffusion and biodistribution. Hum Gene Ther 2009;20:350-360.

184. Wolf DA, Lenander AW, Nan Z, et al. Direct gene transfer to the CNS prevents emergence of neurologic disease in a murine model of mucopolysaccharidosis type I. Neurobiol Dis 2011; 43:123-133.

185. Fu H, DiRosario J, Kang L, et al. Restoration of central nervous system $\alpha$ - $N$-acetylglucosaminidase activity and therapeutic benefits in mucopolysaccharidosis IIIB mice by a single intracisternal recombinant adeno-associated viral type 2 vector delivery. J Gene Med 2010;12:624-633.

186. Hironaka K, Yamazaki Y, Hirai Y, et al. Enzyme replacement in the CSF to treat metachromatic leukodystrophy in mouse model using single intracerebroventricular injection of selfcomplementary AAV1 vector. Sci Rep 2015;5: 13104.

187. Yamazaki Y, Hirai Y, Miyake K, et al. Targeted gene transfer into ependymal cells through intraventricular injection of AAV1 vector and longterm enzyme replacement via the CSF. Sci Rep 2014;4:5506.

188. Spampanato C, De Leonibus E, Dama P, et al. Efficacy of a combined intracerebral and systemic gene delivery approach for the treatment of a severe lysosomal storage disorder. Mol Ther 2011;19:860-869.

189. Rafi MA, Rao HZ, Luzi P, et al. Extended normal life after AAVrh10-mediated gene therapy in the mouse model of Krabbe disease. Mol Ther 2012;20:2031-2042.

190. Polito VA, and Cosma MP. IDS crossing of the blood-brain barrier corrects CNS defects in MPSII mice. Am J Hum Genet 2009;85:296-301.

191. Jung SC, Park ES, Choi EN, et al. Characterization of a novel mucopolysaccharidosis type II mouse model and recombinant AAV2/8 vector- mediated gene therapy. Mol Cells 2010;30:1318.

192. Duncan FJ, Naughton BJ, Zaraspe K, et al. Broad functional correction of molecular impairments by systemic delivery of scAAVrh74-hSGSH gene delivery in MPS IIIA mice. Mol Ther 2015; 23:638-647.

193. McCarty DM, DiRosario J, Gulaid K, et al. Mannitol-facilitated CNS entry of rAAV2 vector significantly delayed the neurological disease progression in MPS IIIB mice. Gene Ther 2009; 16:1340-1352

194. Hinderer C, Bell P, Gurda BL, et al. Liver-directed gene therapy corrects cardiovascular lesions in feline mucopolysaccharidosis type I. Proc Nat Acad Sci U S A 2014;111:14894-14899.

195. Murrey DA, Naughton BJ, Duncan FJ, et al. Feasibility and safety of systemic rAAV9hNAGLU delivery for treating mucopolysaccharidosis IIIB: toxicology, biodistribution, and immunological assessments in primates. Hum Gene Ther Clin Dev 2014;25:72-84.

196. Rockwell HE, McCurdy VJ, Eaton SC, et al. AAVmediated gene delivery in a feline model of Sandhoff disease corrects lysosomal storage in the central nervous system. ASN Neuro 2015;7.

197. Gray-Edwards HL, Brunson BL, Holland M, et al. Mucopolysaccharidosis-like phenotype in feline Sandhoff disease and partial correction after AAV gene therapy. Mol Genet Metab 2015;116: 80-87.

198. Fu H, Kang L, Jennings JS, et al. Significantly increased lifespan and improved behavioral performances by rAAV gene delivery in adult mucopolysaccharidosis IIIB mice. Gene Ther 2007:14:1065-1077.

199. Elliger SS, Elliger CA, Lang C, et al. Enhanced secretion and uptake of $\beta$-glucuronidase improves adeno-associated viral-mediated gene therapy of mucopolysaccharidosis type VII mice. Mol Ther 2002;5:617-626.

200. Kiyota T, Yamamoto M, Schroder B, et al. AAV1/ 2-mediated CNS gene delivery of dominantnegative CCL2 mutant suppresses gliosis, $\beta$ amyloidosis, and learning impairment of APP/ PS1 mice. Mol Ther 2009;17:803-809.

201. Saal KA, Koch JC, Tatenhorst L, et al. AAV. shRNA-mediated downregulation of ROCK2 attenuates degeneration of dopaminergic neurons in toxin-induced models of Parkinson's disease in vitro and in vivo. Neurobiol Dis 2015;73:150162.

202. Alto LT, Chen X, Ruhn KA, et al. AAV-dominant negative tumor necrosis factor (DN-TNF) gene transfer to the striatum does not rescue medium spiny neurons in the YAC128 mouse model of Huntington's disease. PLoS One 2014;9:e96544.

203. Boudreau RL, McBride JL, Martins I, et al. Nonallele-specific silencing of mutant and wildtype huntingtin demonstrates therapeutic efficacy in Huntington's disease mice. Mol Ther 2009;17:1053-1063. 
204. Connor B, Sun Y, von Hieber D, et al. AAV1/2mediated BDNF gene therapy in a transgenic rat model of Huntington's disease. Gene Ther 2016;23:283-295.

205. Klein RL, Hirko AC, Meyers CA, et al. NGF gene transfer to intrinsic basal forebrain neurons increases cholinergic cell size and protects from age-related, spatial memory deficits in middleaged rats. Brain Res 2000;875:144-151.

206. McBride JL, Pitzer MR, Boudreau RL, et al. Preclinical safety of RNAi-mediated HTT suppression in the rhesus macaque as a potential therapy for Huntington's disease. Mol Ther 2011;19:2152-2162.

207. Emborg ME, Carbon M, Holden JE, et al. Subthalamic glutamic acid decarboxylase gene therapy: changes in motor function and cortical metabolism. J Cereb Blood Flow Metab 2007;27:501-509.

208. Stoica L, Todeasa SH, Cabrera GT, et al. Adenoassociated virus-delivered artificial microRNA extends survival and delays paralysis in an amyotrophic lateral sclerosis mouse model. Ann Neurol 2016;79:687-700.
209. Wang H, Yang B, Qiu L, et al. Widespread spinal cord transduction by intrathecal injection of rAAV delivers efficacious RNAi therapy for amyotrophic lateral sclerosis. Hum Mol Genet 2014;23:668-681.

210. Mussche S, Devreese B, Nagabhushan Kalburgi $S$, et al. Restoration of cytoskeleton homeostasis after gigaxonin gene transfer for giant axonal neuropathy. Hum Gene Ther 2013;24:209-219.

211. Borel F, Gernoux G, Cardozo B, et al. Therapeutic rAAVrh10 mediated SOD1 silencing in adult SOD1 ${ }^{\text {G93A }}$ mice and nonhuman primates. Hum Gene Ther 2016;27:19-31.

212. Dufour BD, Smith CA, Clark RL, et al. Intrajugular vein delivery of AAV9-RNAi prevents neuropathological changes and weight loss in Huntington's disease mice. Mol Ther 2014;22:797810 .

213. Franz CK, Federici T, Yang J, et al. Intraspinal cord delivery of IGF-I mediated by adeno-associated virus 2 is neuroprotective in a rat model of familial ALS. Neurobiol Dis 2009;33:473-481.
214. Sorensen AT, Nikitidou L, Ledri M, et al. Hippocampal NPY gene transfer attenuates seizures without affecting epilepsy-induced impairment of LTP. Exp Neurol 2009;215:328-333.

215. Noe F, Pool AH, Nissinen J, et al. Neuropeptide $Y$ gene therapy decreases chronic spontaneous seizures in a rat model of temporal lobe epilepsy. Brain 2008;131:1506-1515

216. Haberman $R$, Criswell $H$, Snowdy $S$, et al Therapeutic liabilities of in vivo viral vector tropism: adeno-associated virus vectors, NMDAR1 antisense, and focal seizure sensitivity. Mol Ther 2002;6:495-500.

217. Storek B, Reinhardt M, Wang C, et al. Sensory neuron targeting by self-complementary AAV8 via lumbar puncture for chronic pain. Proc Natl Acad Sci U S A 2008;105:1055-1060

Received for publication June 7, 2016; accepted after revision June 7, 2016

Published online: June 7, 2016 